\title{
Political Connections and Corporate Financial Decision Making
}

\begin{abstract}
This paper investigates whether political connections influence managerial financial decisions. Our study reveals that those firms that have a politician on its board of directors are highly leveraged, hold large excess cash and are associated with low quality financial reporting compared to their non-connected counterparts. These effects escalate with the strength of the connected politician and whether he or his party is in power. The winning party effect is observed to be stronger than victory by the politician himself. Overall, our paper provides strong evidence that political connection is a two-edged sword. It is indeed a valuable resource for connected firms, but it comes at a cost of poor investor protection.
\end{abstract}

Keywords: Political connection; Earnings management; Financial policies. 


\section{Introduction}

The effect of political connections on business is well recognized, but not well understood. It is generally argued that firms secure economic benefits and advantages from connections with politicians (Xu et al., 2018; Batta et al 2014; Faccio, 2010), particularly in less developed markets (Pan and Tian, 2018; Batta et al 2014; Chen et al., 2011; Claessens et al., 2008). For instance, Muttakin et al. (2015) show that politically connected family firms outperform nonconnected family firms in Bangladesh. Claessens et al. (2008) reveal that bank finance is an important channel through which political connections operate in Brazil. On the other hand, some studies have provided evidence that political connection weakens the corporate board governance (Fan et al., 2008) and reduces managerial incentives to maximize shareholder wealth (Bertrand et al., 2018; Ding et al., 2015). A more recent study among Venezuelan industrial firms facing expropriation risk by Batta et al (2014) shows that politically connected firms have higher accounting quality than non-connected firms.

The foregoing studies suggest that political connection, if anything, has a "two-edged sword" effect on the firm. As such, we posit that in order to fully appreciate the effect of political connection, we need to look at a broad set of firm policies. In this study, we examine the impact of political connections, in Pakistan, on a broad set of financial policies, including firm leverage, long-term debt, excess cash holdings and accruals management. We focus on these policies because, as key elements of financial strategy and corporate risk taking, they represent a set of factors most likely to be affected by political connections.

There are several reasons why Pakistan is particularly interesting for the study we propose. First, the vast majority of the population, around 95\%, is Muslim. The basic tenet of Islam requires business practices to be conducted in an honest and fair manner as Muslims believe in the eternal concept of life, in which honesty is rewardable and dishonesty punishable. Following the view that religious beliefs influence the personality traits, e.g., honesty and work ethics, which may affect economic outcomes (Saeed et al., 2015), it is expected that managers would refrain from involving in such transactions that violate the core Islamic values. Second, despite the religious element, Pakistani politicians and firms are well known for their cozy relations (Khwaja and Mian, 2005). Over the last fifteen years, three prime-ministers and their governments were dismissed due to political patronage and misuse of power, which shows the pervasiveness of corruption within the country. Third, because of the weak democratic institutions, an underdeveloped financial sector and the state-ownership of banks, political connections are likely to be particularly valuable, especially through government dictated 
preferential access to government bank credit. Moreover, Pakistan imposes no legal restrictions on political influence on the private sector (Rehman, 2006). This partly explains the high proportion of politically connected firms in Pakistan. Lastly, like many other developing economies, Pakistan has adopted a Western-style corporate governance model which requires greater board independence and separation of the CEO and chairperson. However, the effectiveness of these governance measures could be compromised due to the weak institutional environment (Javid, 2010). These characteristics of the Pakistani economy furnish a fertile field to ascertain the effect of the two-edged sword political connection.

Given that the impact of connections largely depends on the level of the institutional and economic development of the country (Lee \& Wang, 2017; Muttakin et al., 2015; Faccio, 2006), we contend that, in the context of Pakistan, the benefit of political connection comes from easy access to bank financing. Easy access to finance is usually greater when the firm operates in a country with a high level of corruption among its officials, low protection of property rights, a high interventionist government, or a nondemocratic government (Pan and Tian, 2018; Faccio 2006). Moreover, in Pakistan the majority of corporate external financing is through the banking sector (Ahsan et al., 2016). As argued by Chava and Puranandum (2010), short-term debt is considered a riskier financing decision (compared to long-term debt) because it exposes firms to refinancing and interest rate risks. Hence, we also investigate the use of long-term debt and short-term debt to gain a better understanding of the effect of political ties on firm leverage.

We also study two other aspects of corporate decision making, namely the excess cash holdings and the earnings management decisions. Politically connected firms in Pakistan are less likely to be financially constrained because of the easy access to finance that they enjoy through their political ties. More specifically, connected firms are able to evade the high transaction costs and financial market uncertainties because of privileged treatment in the credit market. Effectively, these firms do not have an incentive to hoard liquid assets at similar levels to those firms lacking such relationships (Hill et al., 2014). Consequently, the demand for cash reserves becomes further weakened. In this regard, we posit that firms holding a large amount of excess cash, in the absence of transaction or uncertainty motives can be interpreted as an indication of an agency problem as excess cash increases the propensity of managers to squander excess cash. To delve further into the deleterious effect of political connections, we argue that to camouflage the impact of resources used for political objectives, politically connected firms are more likely to manipulate their accounting information. Consequently, low quality reporting is expected from the politically connected. Collectively, our contention is 
based on the evidence provided by earlier studies that connected firms suffer from poor corporate governance due to political interventions (e.g., Bertrand et al., 2018; Khan et al., 2016; Muttakin et al., 2015; Boubakri et al., 2013). Thus, poor corporate governance coupled with the easy access to credit increases the propensity of managers to adopt policies that can help them in pursuing political objectives at the expense of the shareholders, which includes holding excessively large cash balances and low reporting quality.

To examine these contentions, we use a sample of 403 Pakistani listed non-financial firms over the period 2002-2010. Panel regressions are estimated independently for each aforementioned financing policy. We define politically connected firms as those that have a politician on their board of directors and find that political connections exert a positive and significant impact on firm leverage. We also find that connected firms have more leverage than non-connected firms, which is evidence supporting the existence of politically motivated credit allocation. Interestingly, we find that the effect of political connections varies with respect to the success of the individual politician as well as with respect to the success of his affiliated party. For example, a winning politician has more impact than a losing politician while a winning politician from a winning party has the greatest impact. Our additional results reveal that connected firms have a higher percentage of long-term debt than their non-connected counterparts. On the other hand, connections do not have any impact on short-term debt. Keeping in view the prevalence of short-term debt in a developing economy such as Pakistan, where banks use short-term leverage as a monitoring tool, our results are strong evidence supporting the relationship between political connectedness and financial advantage. The drawback to short-term debt is that it is a riskier financing vehicle than long term debt because it exposes firms to refinancing as well as interest rate risks. Longer loan deals also make it possible to reduce the risk of renegotiating when their politician and/or his party is out of power. Given the fragile political environment within the country (in the last two decades three elected governments in Pakistan were dissolved before even completing their half-terms), this is an important consideration.

We next investigate how political connections influence excess corporate cash holdings. High excess cash signals the presence of agency problems (e.g. Belghitar and Clark, 2014; Ozkan and Ozkan, 2004; Opler et al., 1999; Dittmar et al., 2003). We document that politically connected firms hold larger amounts of excess cash than their non-connected peers. Our result contradicts the conventional wisdom that easy access to credit lowers the likelihood among connected firms to suffer liquidity constraints so it is unlikely for them to hold large cash. Nevertheless, our result is in line with the agency theory. Drawing on agency theory, 
earlier studies (e.g., Bertrand et al., 2018; Muttakin et al., 2015; Kostovetsky, 2015; Ding et al., 2015; Faccio, 2010) document that connected firms face severe agency problems, as they have weak firm-level governance and boards in connected firms cannot play their monitoring role due to the political interventions. So, poor corporate governance coupled with the easy access to external finance may lead managers of connected firms to adopt policies that may help them in pursuing their personal objectives at the cost of shareholders, which includes holding large cash balances available to be squandered by consuming perquisites such as the pursuit of political objectives. This effect increases with the power of the politician depending on whether he and/or his party are winners.

We also assess the quality of financial reporting by looking at the relationship between political connections and accruals management. Reporting corporate earnings in a 'true and fair' manner that permits outsiders to monitor their claims and exercise their rights is a crucial requirement for effective corporate governance (e.g., Ben-Nasr et al. 2015). Our empirical findings for accruals management show that the presence of political connections reflects a lower quality of financial reporting. Further, we report that the extent of accruals manipulation escalates with the strength of the connected politician. The interpretation of our results is that politically connected firms derive gains from their connections in the form of higher leverage and more utilization of long-term debt, and concurrently hold large amounts of free cash-potentially with the intention of misusing it. In this way, firms attempt to hide the political benefits and political expenditure with the purpose of intentionally misleading shareholders to gain benefits at their expense.

Taken together, we can draw three broad conclusions from our results. First, our findings indicate that connected firms utilize more leverage (more long-term debt), hold larger excess cash balances and have lower quality financial reporting. These results are robust to a battery of tests including the use of alternative measures for financial policies, an alternative and broader definition of political connections, the use of instrumental variables, as well as to additional control variables of corporate governance. We interpret our results for large excess cash balances and low quality financial reporting as an indication of poor governance which is associated with the agency problems. Secondly, we find that having connections with a winning politician or a politician affiliated with the ruling party has a strong impact on the firms' financing policies, thereby implying that the costs and benefits associated with political connections ultimately rest on electoral outcomes. One aspect worth mentioning is that the winning party effect is more pronounced than the winning politician effect. This finding can 
be attributed to the fact that since the ruling party has control of managing and distributing governmental and quasi-governmental financial resources, affiliated politicians have more influence in determining how these resources are allocated. Lastly, the appointment of a politician to a board is an important source of financial resources for a firm, although it entails a corresponding cost in the form of potential agency problems. Thus, results presented herein should not be interpreted as a recommendation for corporate political activity, as we collectively report the benefits and costs faced by firms that establish political connections. The study, however, is silent on the cost-benefit calculus which determines the decision of whether or not to establish political connections.

These results contribute to the large corporate finance and accounting literature by highlighting a previously under-appreciated determinant of corporate financial decisions (e.g. Frank and Goyal, 2009; Walsh and Ryan, 1997). Previous studies have focused primarily on corporate finance theories (e.g., trade off and pecking-order theories) that have very little to say about the role of political connectedness. We find, however, that political influence plays a significant role in the financial policies of Pakistani firms and, thus, the political aspect needs to be included in theoretical models that examine corporate financial policies. In addition, this study contributes to the extant literature on the relation between political connections and corporate outcomes. Most of the earlier studies look at corporate policies independently and use highly dissimilar types of connections, making it difficult to grasp the overall impact of political ties on corporate policies. ${ }^{1}$ This study provides a more comprehensive picture of the political connections-corporate policies nexus by incorporating four essential financial policies in a single study and documents that the impact of political connectedness on financial policies varies with the political strength of the politician.

The layout of this article is as follows. Section 2 describes the institutional environment in Pakistan. Section 3 provides some theoretical background and develops the hypotheses. Section 4 describes the data and summary statistics; Section 5 presents univariate comparison. The main empirical results are reported and discussed in Section 6 and, finally, Section 7 concludes the paper.

\footnotetext{
${ }^{1}$ The only notable exceptions are Faccio (2010) and Boubakri et al. (2012). Faccio examines the impact of political connections that firms can have on leverage, taxation, market share, productivity and performance, whereas Boubakri et al. report the effects of political connectedness on a firm's leverage and operating performance.
} 


\section{Institutional environment in Pakistan}

Pakistan's financial system has been highly skewed towards the banking sector that accounts for 95 percent of the financial sector with an asset size of 42.6 percent of GDP (Hameed et al., 2013). Banks mainly serve the needs of the government, public sector organizations, and a few very large family firms, while small and medium-sized firms and the agricultural sector are predominantly absent from the equation. The most important reason for this lending pattern is the political interference in both lending decisions and banks' top management (board appointments) (Khwaja and Mian, 2005). Consequently, private sector lending is given based on political considerations rather than on merit which makes the recovery rate so low that the percentage of non-performing loans has ranged between 16.2 and $23.4 \%$ during the period 2000-2011 (International Monitory Fund, 2016), a rate that is much higher than other developing countries in the region, such as India (4.9\%). Additionally, the tax rate for the banking industry is $58 \%$ compared to $35 \%$ for the corporate sector (Husain, 2012). The cost of the high punitive tax rate along with the burden of non-performing loans is passed on to the customers in the interest rate, which has been about $21 \%$ per annum over last decade (Husain, 2012).

One of the important reasons for the immaturity of the financial sector is the political interference. Political influence in the banking sector leads to limited autonomy of the central bank of Pakistan, State Bank of Pakistan (SBP), since all financial and administrative decisions made by the SBP are subject to approval of the Ministry of Finance that arguably serves the interests of the government (Khan, 2018). The appointment of the head of SBP is also made by the sitting government, which it generally does on the basis of political ties (Kundi, 2017). Consequently, the entire financial system has suffered from considerable political interference in lending and collection activities. It is important to mention that despite the partial privatization of some leading banks in Pakistan (e.g. ABL, HBL and MCB), the government continues to influence their decisions as $49 \%$ of their shares are still owned by the government (State Bank of Pakistan, 2017). In August 2015, the government passed the 'State Bank of Pakistan (Amendment) Bill 2015' that empowers the SBP to take financial decisions independently. However sceptics have raised concern about the efficiency of this initiative because the autonomy is linked with political will and the continuation of old policies (Khan, 2018).

Another important aspect of the Pakistani financial market is the limited role of the stock market in raising capital. The Karachi Stock Exchange (KSE) is the main exchange in Pakistan. 
Like many other emerging markets, KSE is able to attract only a handful of new listings and raises little capital. The number of new listings during the period 2002-2012 was 4 per year with the exception of 2010 when 6 new companies were listed. Moreover, KSE is regarded as a highly manipulated market. For example, Khwaja and Mian (2005) show that brokers use a trade-based 'pump and dump' price manipulation strategy to benefit themselves. The result of all this is a marginal equity market with weak investor confidence that attracts few outsiders and raises relatively small amounts of capital. Regarding insolvency laws, Pakistan does not have a bankruptcy law (Jamal, 2015). Bankruptcy is generally handled through court-appointed liquidators who sell off the property of a bankrupt company, but this process is slow and can take years (International Business Promotion, 2015).

Despite the structural reforms initiated in the early 2000s to attract foreign direct investment (FDI) in the country, the level of FDI has declined sharply over the last five years (Zaheer, 2016). Researchers attribute this decline to the deteriorating security environment, poor governance, the chronic energy crisis, a lack of privatization since 2008, and macroeconomic instability (Shah et al., 2016; Anwar and Afza, 2014). Owing to these market characteristics Pakistan has slipped to $127^{\text {th }}$ place in 2014 from $74^{\text {th }}$ in 2007 in the Doing Business Ranking published annually by the World Bank and the International Finance Corporation.

Corruption, which has grown considerably in the last three decades, is endemic, pervasive and deeply entrenched (Saeed et al., 2015). It is another key factor in the Pakistani economy that has repelled foreign as well as domestic investment. The international corruption monitor (The World Justice Project) ranked Pakistan $106^{\text {th }}$ among 113 countries in terms of rule of law in 2016 (World Justice Project, 2016). According to Stevenson (2003), an estimated 30 percent of the price of all public works projects in Pakistan goes to kickbacks and bribes. The reasons for such widespread corruption can be attributed to political instability, the absence of the rule of law, poor regulatory quality, and the lack of accountability, just to mention a few. As Noor (2009) has shown, since Pakistani independence in 1947, the civil and military bureaucracies in Pakistan have continued strolling along the familiar paths of unbridled power, unquestioned authority, and political patronage, thereby playing a major role in the escalating corruption in the socio-political and economic spheres of the country.

Pakistan has suffered instability in its political climate due to the institutional clashes since its very beginning. The military has constantly meddled in its national politics, whereas the judicial system has also been accused of political bias (Shakeel, 2018). In the last two and half decades, no elected prime-minister has been able to complete the full five year term. In 
particular, three elected governments have been dismissed by the sitting presidents $(1990,1993$ and 1996), one elected government was dissolved in 1999 by the military and recently in 2012 and 2017 two elected prime ministers were disqualified by the judiciary. Consequently, besieged with a feeling of uncertainty over their future, politicians have indulged in the distribution of patronage to their connected firms as well as to self-enrichment.

\section{Previous related work and hypotheses}

The resource-based view of the firm argues that the firm's competitive advantage originates from its valuable resources that cannot easily be imitated by competitors (Wernerfelt, 1984). Some of these resources may be intangible in nature and unique to the firm. Among these, some may be relationship-based, such as those where the earnings potential depends on stakeholder relationships (Godfrey, 2005). The political economy literature has long noted that institutional resources, such as government institutions, officials and policies, can be captured and exploited by individual firms in order to gain a competitive advantage (Bertrand et al., 2018; Oberman, 2004). Anecdotal evidence indicates that political ties enable firms to build government support in at least three ways. First, political connections may help firms to gain preferential access to credit in the financial market at a lower cost. A number of recent studies provide support for this assertion. For instance, Pan and Tian (2018) and Boubakri et al. (2008) show that connected firms enjoy preferential treatment in the credit market and maintain higher leverage ratios at lower interest rates. Second, firms can benefit from direct governmental support in the form of receiving government contracts, reduced regulatory requirements, and tax rebates. In this regard, Pan and Tian (2018) document that firms receive bank loans on the basis of their political connections. Goldman et al. (2009) show that political connections facilitate firms in receiving procurement contracts. Similarly, in the Indonesian market, Mobarak and Purbasari (2006) revealed the role of political ties in granting import licenses at the expense of their competitors. Lastly, connected firms even enjoy preferential treatment from the judicial system in bankruptcy court proceedings. Faccio (2006) shows that politically affiliated firms are more likely to be bailed out in the event of financial distress compared to their non-connected counterparts. Indeed, Khwaja and Mian (2005) show that connected firms have a $50 \%$ higher default rate and are more likely to write-off their loans from the courts.

\subsection{Leverage and political connections}

Anecdotal evidence shows that political connections are valuable for firms and that much of this value comes from preferential access to debt. Extant literature has reported that firms with 
political connections enjoy exceptional access to government loans and are in turn more likely to use excessive leverage in financing decisions (Pan and Tian, 2018; Saeed et al., 2015; Ebrahim et al., 2014; Desai \& Olofsgard, 2011; Claessens et al., 2008). This view depicts a positive association between political connectedness and the level of financial leverage. However, some studies also show the negative or complete lack of a link between political connectedness and financial leverage (e.g., Bunkanwanicha \& Wiwattanakantang, 2009). Given the Pakistani context and following the widely held empirical findings, we expect a positive relationship between political connections and leverage.

Hypothesis 1: There is a positive relationship between political connections and leverage.

\subsection{Excess cash and political connections}

As shown by prior studies, connected firms benefit from easy access to finance and are more likely to be bailed out in the event of financial distress (Boubakri et al. 2008; Faccio 2006; and Khwaja and Mian, 2005). They are, therefore, unlikely to hoard large cash as a precautionary or transactions motives ${ }^{2}$ (Hill et al., 2014). However, from the agency perspective, connected firms are considered as poorly governed and subject to more severe agency problems (Chaney et al., 2011). More specifically, poor corporate governance leads to higher accumulation of cash balances in connected firms, particularly given that top management in connected firms have to obey political objectives, which may clash with the shareholders' wealth maximization objectives (Boubakri et al., 2013). Additionally, boards within the connected firms are unable to play their monitoring role due to political pressure (Faccio, 2010). Thus, easy access to credit coupled with poor corporate governance may induce managers of connected firms to increase their cash balances for use in the pursuit of political objectives at the expense of shareholders. Importantly, considering the poor corporate governance and political instability in Pakistan (mainly due to the outsized role of the military and judiciary in politics) ${ }^{3}$, it is expected that connected firms are more likely to reap the immediate benefits from their connections instead of waiting for future benefits. In this case, we suggest that rather than relying on political

\footnotetext{
2 The existing literature puts forth two main arguments for holding large cash balances: the transaction cost motive and the precautionary cost motive (Hill et al., 2014; Ozkan and Ozkan, 2004). The former emphasises that firms incur higher transaction costs to generate cash reserves and, therefore, tend to hold larger cash reserves. On the other hand, the latter motive asserts that firms accumulate liquid assets to meet unexpected contingencies and also to finance the future investments if the cost of external finance is prohibitively high. In contrast, Jensen (1986) argues that large internal funds may increase the agency costs by enhancing the entrenched manager's autonomy, which consequently weakens the market discipline.

${ }^{3}$ As discussed in section-2, in the last two and half decades, six elected governments were dissolved-a direct reflection of political instability and state of uncertainty in the Pakistani institutional setting.
} 
connections as a precautionary measure, connected firms in Pakistan amass large cash balances that are facilitated by having easier access in credit market. Thus, considering poor corporate governance and political uncertainty, we expect a positive relationship between political connections and excess cash holding.

Hypothesis 2: There is a positive relationship between political connections and excess cash holding.

\subsection{Accruals management and political connections}

It is generally held that political connections lead to lower quality financial reporting. According to this dominant view, political connections may cause agency problems by leading management to manipulate earnings to hide the tunneling - and expropriation of other shareholders - of corporate resources for political objectives (e.g., Xu et al., 2018; Aggarwal et al., 2009; Khan et al., 2016; Boubakri et al., 2013 among others). For instance, Chaney, et al. (2011) argue that politically connected firms face less market pressures to enhance the quality of their financial and accounting information than non-connected firms. Therefore, connected firms have a higher level of abnormal accruals. They affirm that politically connected directors have generally more incentives to tunnel corporate resources for political benefits, such as employment to their political supporters, promoting regional development by locating production in politically desirable rather than economically suitable areas and for campaign donations. To hide this expropriation, connected directors may lead managers to manipulate earnings, which results in a lower quality of earnings. Furthermore, a higher cost of debt as an incentive to improve the quality of their financial reporting is only pertinent to non-politically connected firms. Likewise, Ben-Nasr et al. (2015) observe a negative link between political connections and the quality of reported earnings and show that state-owned firms, which are generally characterized as politically connected, are associated with higher agency problems. This evidence suggests that connected firms have objectives other than wealth maximization for which they need to tap corporate resources. The firms then use earnings management to conceal these costs from the other stakeholders. However, another point of view suggests that the risk of government expropriation leads connected firms to maintain higher levels of accounting quality (Batta et al., 2014). Following the conclusions of the mainstream literature, we expect to observe a negative relationship between political connections and accounting quality and state our last hypothesis as follows: 
Hypothesis 3: There is a negative relationship between political connections and the quality of reported earnings (accruals quality).

\section{Data and variable measurement}

\subsection{Data}

The firm-level data used here is obtained from OSIRIS, which contains specific report format data on the finances and board structure of over 70,000 globally listed firms. Next, our source for business group affiliation is Rehman (2006) that provides a comprehensive list of large business groups and their associated companies in the Pakistani market. Data on politicians is required to identify the firm's connections with politicians. To this end, we depend on the database provided by the Election Commission of Pakistan (ECP). The ECP is responsible for conducting elections on both National and Provincial levels and it maintains the data on candidates participating in these elections, including candidates' names, party association, and electoral results. Given that two general elections (for national and provincial assemblies) held during the last decade — 2002 and 2008 — we, therefore, selected the sample period from 2002 to 2010 to include both of these elections. In each election, there were around 848 constituencies (272 at national level and 577 at provincial level), with approximate 6 to 9 contestants in each constituency, which gives a grant sum of 10,500 candidates in both elections.

The data spans 2002-2010 and includes all listed non-financial companies in Pakistan during that period. To be included in the sample, each firm is required to report at least two consecutive years' financial data in order to observe the changes in the firm's financing structure. After applying this filter we are left with a sample of 403 firms with an unbalanced panel of 2,328 firm-year observations. Of these firms, 116 are identified as politically connected (defined above as a firm having a politician on the board). The politically affiliated sub-sample is further divided based on electoral outcomes and this classification scheme yields 67 firms (57.75\%) connected to winning politicians, and 81 firms $(69.82 \%)$ related to politicians belonging to a ruling party. Descriptive statistics on the sample firms is provided in Table 1.

Our sample includes $28.87 \%$ of politically connected firms having 672 firm-year observations. It includes 114 business group-affiliated firms and 289 stand-alone firms. Groupaffiliated firms constitute $28.28 \%$ of the overall sample and $55.17 \%$ of the connected firms. Furthermore, the companies encompassing foreign ownership comprise $10.42 \%$ of the sample 
and close to $8 \%$ of the connected firms. The main industries include textile (36\%) and basic industries $(16 \%)$.

\subsection{Model}

Since the aim of this study is to examine the influence that political connectedness asserts on financial policies, we regress the financial policy variables on the variable indicating corporate political connection and the control variables used in previous literature. Our empirical analysis uses a regression model of the following general form:

$$
Y_{j, t}=\beta_{0}+\beta_{1} \text { Connected }_{j, t}+\beta_{2} Z_{j, t}+\text { DumYear } \text { DumInd }+\varepsilon_{j, t}
$$

$\mathrm{Y}$ is the dependent variable indicating four financial policy variables. Connected is a variable capturing the corporate political connectedness. To distinguish between the impact of a politician's influence on the financial policies of a connected firm, we use two additional alternative measures for political connectedness. Connected 1 is a dummy variable that takes 1 if the firm is connected to a politician who wins the elections and 0 otherwise. Connected 2 is a dummy that equals 1 if the firm is connected to a politician who is a member of the ruling party and 0 otherwise. Collectively, Connected 1 and Connected 2 capture the politician winning effect and the party winning effect, respectively. $Z$ is a vector of firm-level control variables. These control variables are independently discussed for each financial policy variable in the next section. DumYear and DumInd represent year and industry dummies. Following Campbell (1996) and Saeed et al. (2015), we reclassified two-digit SIC to a narrower one of eight industry categories. These categories include: Food \& Tobacco (Ind_Food), Basic industries including Petroleum (Ind_Basic), Construction (Ind_Const), Textile \& trade (Ind_Textile), Consumer durables (Ind_Consumer), Transportation (Ind_Transp), Services (Ind_Services), and Others. Thus, seven industry dummies are included in our model to control industry effects. The regressions are carried out using the panel data regression model with heteroscedasticityconsistent robust standard errors clustered at the firm's level to control for serial correlation in the residuals ${ }^{4}$.

\subsection{Key variable measurement}

\footnotetext{
${ }^{4} \mathrm{We}$ also assess the robustness of our results to the instrumental variable technique (Heckman two-stage analysis), which will be discussed in the section 6.3.
} 
Leverage: The first dependent variable in this study is leverage. Most Pakistani firms do not issue bonds to raise finance-due to the underdevelopment of the capital market- but rather use bank loans as a financing source (Ashraf and Ghani, 2005). Therefore, the leverage of Pakistani firms is regarded as a bank loan and calculated as book value. In addition, Myers (1977) justifies the use of book values on the basis that the book value of leverage relates to the value of assets in place and does not normally include the capitalisation value of future growth opportunities that makes book values a more stable measure. In this study, Leverage is defined as the ratio of the book value of a firm's total debt (short-term and long-term) to the total assets. We further divide leverage into long-term and short-term debt. Following Scherr and Hulburt (2001), the long-term debt variable is calculated as long-term debt divided by its total debts, where long-term leverage is measured as a firm's debt maturing in more than one year.

Excess cash holdings: Dittmar and Smith (2007) pointed out that raw "total cash holdings" fails to account for the possibility of positive effects of sufficient cash resources needed for daily operations. Poorly monitored managers may, however, waste excess cash, which is the cash held above some optimal level. To estimate this optimal level, we regress total cash holdings on a set of variables generally considered as important determinants of cash holdings. Specifically, we adopt the cash holdings model used by Opler et al. (1999) and Dittmar et al. (2003), which has the following form:

$$
\begin{gathered}
\text { CASH }_{j, t}=\beta_{0}+\beta_{1} T A_{j, t}+\beta_{2} C F_{j, t}+\beta_{3} N W C_{j, t}+\beta_{4} \text { SaleGrowth }_{j, t}+\beta_{5} \text { Liabilities }_{j, t}+ \\
\text { DumYear }+ \text { DumInd }+\varepsilon_{j, t}
\end{gathered}
$$

where $C A S H$ is the ratio of cash to total assets, $T A$ represents the natural logarithm of total assets, $C F$ is the cash flow measured as cash flow less capital expenditure less interest expense divided by total assets, $N W C$ represents net working capital calculated as current assets minus cash and current liabilities divided by total assets. This measure is also used in earlier related studies such as Ozkan and Ozkan (2004); Dittmar et al. (2003); and Opler et al. (1999). Net working capital is considered as a cash substitute as it easily converted into cash (Anagnostopoulou, 2013; Opler et al., 1999; Ozkan and Ozkan, 2004). Therefore, firms with a higher level of net working capital should have lower cash reserves. SaleGrowth indicates sales growth which is the growth in the prior year's sales, Liabilities is total liabilities divided by total assets, DumYear are time dummies, DumInd are seven dummies at the two-digit level 
of SIC and $\varepsilon$ is the error term. The residuals from the above equation are used to compute excess cash, Excess Cash.

Accruals management: Following Kothari et al. (2005), and Hazarika et al. (2012), we measure accruals management as the absolute value of abnormal accruals. This is because the discretionary accruals can be utilized to increase or decrease reported earnings. For example, to boost the equity based compensation and to make new equity issues more lucrative to outside investors, the managers may manipulate earnings upwards. On the other hand, before a reissue of options or share repurchase the managers have incentives to manipulate earnings downward. Thus, we use the absolute value of abnormal accruals to estimate the extent of managerial earnings manipulation. Additionally, to measure the impact of political connection on the level of accruals we also use the original value of accruals.

Measurement of firm political connection: Following the literature on corporate political connectedness (Lee \& Wang, 2017; Shen \& Lin, 2016; Faccio, 2006; Infante \& Piaza, 2010; Boubakri et al., 2013), a firm is defined as connected if it has a politician on its Board of Directors. A politician is defined as any individual who stood in the national or provincial elections. Data on politicians (electoral candidates that contested the elections of 2002 and 2008) is taken from Pakistan Election Commission. This politician dataset includes comprehensive information on the candidates including their names, party affiliation, electoral outcomes, and number of votes received by each candidate. Each politician is uniquely identified by a combination of first and last name. In Pakistan, the first name includes both given name and middle name, whereas the last name generally refers to the caste. For instance, for Muhammad Ali Chaudary, the first name is Muhammad Ali and Chaudary is the caste which is considered as a last name. It is extremely rare, if not impossible, for politicians to have the same first and last/caste name. Nevertheless, as a preliminary test, we check and compare the politicians' names and found no anomalies. Information about Board of Directors is obtained from OSIRIS database. In last, the complete names of directors are matched against the name of each politician. If we get a precise match then that organization is considered as a politically connected. In doing so, we found 116 politicians' names were matched with the directors' names. Importantly, no politician was found to be associated with more than one firm. Consequently, 116 firms were considered as politically affiliated firms ${ }^{5}$.

\footnotetext{
${ }^{5}$ To avoid human error, the sample selection process (matching of politicians with the names of directors) is performed by applying programming-code.
} 


\section{Univariate comparison}

For convenience Table 2 provides the empirical definition of the variables used in the analysis, while Table 3 shows their descriptive statistics. In order to control for the potential influence of outliers, all variables are winsorised at the 5th and 95th percentiles. The mean value of the cash balances of the sample firms is Rs. 286,162 and the standard deviation is 601,539 . The average book leverage ratio of sample firms in their capital structure is 0.66 and the standard deviation is 0.26 . The long-term leverage ratio is lower with the mean and standard deviation of 0.25 and 0.21 , respectively. On average, sample firms hold $14 \%$ excess cash. The mean value of accruals management (absolute abnormal accruals) is $10 \%$. Once we split the sample into politically connected and non-connected firms, it can be noted that the values of all financial policy variables, except long-term debts, are higher for connected firms and this difference is statistically significant. The findings suggest that politically connected firms maintain a leverage ratio of 0.68 , compared with a lower 0.63 for firms without connections. This result is consistent with the argument of preferential treatment for connected firms in the credit market. Similarly, the mean value of excess cash of connected firms is $17 \%$, whilst that of non-connected firms in only $11 \%$. The mean abnormal accruals of the connected firms is $12 \%$, compared to $9 \%$ for their non-connected counterparts. However, on average, long-term debt, measured by long-term debt divided by total assets, is not statistically different.

It is found that firms with political ties are larger — measured by asset size - than nonconnected firms, which may explain their higher leverage in the capital structure. Moreover, when compared to non-connected firms, connected firms are found to have more liquid assets but show poor performance. In terms of ownership, connected firms are more domestically owned and linked with business groups. These initial findings suggest that politically affiliated firms have easy access to leverage, maintain large amounts of excess cash and show lower quality accounting information, which indicates the presence of agency problems amongst these firms.

Table 4 shows the correlation matrix of our variables. Variables representing the political connectedness are highly correlated with each other. Such high correlation is not unexpected as the Connected 1 and Connected 2 are the subset of the Connected variable. Besides, none of the independent variables show extreme correlation with each other, showing that multicollinearity is not a serious concern in our regressions.

\section{Empirical analysis}

6.1. Main findings 


\subsubsection{Determinants of corporate political connectedness}

Some firm-level variables are more important than others in influencing the firm's ability to establish political connections. Therefore, it is important to examine which firm characteristics are associated with recruiting a politician to join the board. To investigate the determinants of a firm being politically connected, we estimate a probit model whose dependent variable is political connections which is one of the three political connections indicators (connected, connected1, and connected2). Specifically, the dummy variable of political connection is regressed against the following variables: firm size, profitability, tangible assets, growth opportunities, foreign ownership, business group affiliation, firm quality, tax rate, liabilities, dividend payment, net working capital, large shareholders\%, and board independence. Moreover, an additional variable, the extent of political connections in the connected firm's industry (indus_connection) is also used to control the industry effect. Industries that are heavily regulated and interact with the government are more likely to establish political connections. The measures of all variables are defined in Table 2.

Results presented in Table 5 indicate that firm size, business group affiliation, liabilities, the large shareholdings and extent of political connectedness in an industry have a significant positive influence on the probability that the firm will appoint a politician to the board in Pakistan. It indicates that larger size, business group affiliation, higher liabilities, large shareholdings, and greater extent of politically connected firms in the industry increases a firm's likelihood of establishing political connections. Moreover, the estimates suggest that low performance and dividend non-payment increases a firm's probability of political connectedness. Regarding industries, firms that belong to construction, textile, and transportation are more likely to establish political connections. These findings are generally consistent with earlier research using international data (e.g., Faccio 2006; Boubakri et al., 2013).

\subsubsection{Capital structure}

We start our analysis with the capital structure decision. There are a number of control variables used in the earlier studies that tend to influence the amount of leverage, including size, collateral, profitability, growth opportunities, ownership, business group affiliation, largeshareholders and board-independence. The analysis was restricted to these factors owing to the fact that they have been consistently employed in the earlier studies on capital structure (e.g., Pan and Tian, 2018; Fraser et al., 2006; Charumilind et al., 2006). We define firm size as the 
natural logarithm of annual sales revenue (total sales). It is a widely used proxy in the earlier studies such as Dand et al. (2018); Moosa and Li (2012); Singh and Davidson (2003) and Calof (1994). The ratio of fixed property, plant and equipment to total assets is used. Trade-off theory suggests that firms use tangible assets as a guaranty of loan (Frank and Goyal, 2009). Pecking order theory also suggests a positive relationship between the amount of physical assets and leverage and further suggests that collateral reduces information asymmetry between borrower and lender ${ }^{6}$. Firm profitability is measured by profit before taxes, divided by total assets. The predictions on profitability are ambiguous. Pecking order theory (Myers, 1984) suggests that firms first utilize retained earnings for new investments then move to debt and equity, if required. Following the prediction of Pecking order theory profitable firms are able to generate sufficient cash therefore they must prefer retained earnings over debt and equity. This suggests a negative relationship between profitability and leverage. In contrast, Trade-off theory (Modigliani and Miller, 1958) predicts that profitable firms should use more leverage to offset corporate taxes. There are two corporate decisions that might directly influence the nexus between profitability and leverage: repurchasing of shares and dividend payment ${ }^{7}$. In case of a developing country like Pakistan, repurchasing of shares is a new phenomenon. The Securities and Exchange Commission of Pakistan issued a regulation in August 2016, Listed Companies (Buy-Back of Shares) Regulations, for listed firms to repurchase their shares. On the other hand, dividend payment is not mandatory in Pakistan and minority shareholders are often neglected due to poor corporate governance (Ahmed and Javad, 2009). Consequently, Pakistani listed firms are not very keen to pay dividends (Naeem and Nasr, 2007). Considering the above trends of the Pakistani market, it is safe to assume that the impacts of repurchasing of shares and dividend payment decisions would not influence the relationship between profitability and leverage. In addition, the market-to-book ratio is included as a proxy for growth opportunities. Myers (1977) argues that shareholders have an incentive to forgo value-enhancing investment opportunities if the payoffs of the investment accrue to debtholders, resulting in an underinvestment problem. To remedy this underinvestment problem, shareholders will lower the level of leverage. Thus, a negative relationship exists between leverage and growth opportunities. Empirical studies, by and large, support this relationship (see Frank and Goyal (2005) for a survey). Importantly, a seminal work of Rajan and Zingales (1995) also shows a

\footnotetext{
${ }^{6}$ The Trade-off theory originated with Modigliani and Miller's (1958) famous proposition, while the Pecking order theory was developed by Myers and Majluf (1984) and Myers (1984).

${ }^{7} \mathrm{We}$ are grateful to the referee for pointing out this issue.
} 
negative relationship between growth opportunities, measured as the market-to-book ratio, and leverage in G7 countries ${ }^{8}$. Furthermore, a dummy variable, which takes the value 1 if at least $10 \%$ of its stock is foreign owned, is used to control the effect of foreign ownership. ${ }^{9}$ Finally, the business group effect is controlled by a dummy that equals 1 if a firm is affiliated with the top 30 Pakistani business groups operating in the non-financial sector (based on their sizes) identified in Rehman (2006) and zero otherwise. In line with Su and Fung (2013) and Wu et al. (2012), we employ three variables in our model to measure the corporate governance mechanisms, namely, large-shareholders, board-independence and CEO duality. Large shareholding is measured by the percentage of shares held by the largest shareholders. Board independence is the number of independent directors divided by total number of directors. Lastly, CEO duality is a dummy variable taking the value of 1 if the same person holds the positions of CEO and board chair, and zero otherwise. A widely held view is that boards can perform their monitoring role better when the chair of the board is not occupied by the CEO (Jensen, 1986). Consequently, a strong board may prefer more leverage that serves as a disciplining device. Empirical evidence, such as Jiraporn et al. (2012) and Berger et al . (1997), also support this notion and show a negative relationship between CEO duality and the use of leverage. On the other hand, Zwiebel (1994) documents that powerful managers use more leverage and engage in a greater degree of empire building. In sum, the direction of the relationship between CEO duality and leverage is contentious.

Some unobservable firm-level variables may be influencing both the ability to establish political connections and corporate financing policies which may cause an endogenity issue. To alleviate the endogeneity concern — we estimate our results using the Heckman (1979) twostage model. In the first stage, a probit model is estimated to predict the likelihood that a firm establishes political connections. More specifically, a 0, 1 dummy variable indicating the firm's political connectedness is regressed against the same independent variables used in Model 1 along with one additional (instrumental) variable that differentiates the firm's political connectedness. In the search for a valid instrument we aim to find an exogenous variable that is economically correlated with the political connections variable but not with financial policies. In the spirit of earlier studies such as Ferris et al., (2016) and Wang et al. (2016) the extent of political connections in the connected firm's industry (Indus_connection) is taken as a discerning instrumental variable for political connections. Specifically, it is defined as the

\footnotetext{
${ }^{8}$ However, Chen and Zhao (2006) contend that the relation between the growth opportunities (market-to-book ratio) and leverage is non-monotonic.

${ }^{9}$ We follow Javorcik and Spatareanu (2011) and Kimura and Kiyota (2007) in defining foreign ownership.
} 
number of connected firms in a given industry divided by the total number of firms in that industry. There is a concern that industries which are heavily regulated and interact more often with the politicians are more likely to establish political connection which may bias our estimation ${ }^{10}$. In our case, the proportion of politically connected firms in regulated industries such as petroleum, telecom (services), and tobacco is very low. As shown in panel (c) of Table 1, five politically connected firms (out of 17) belong to the petroleum sector, only one connected firm is from tobacco industry, two firms are from telecoms and one from the power sector. So, collectively in our sample nine connected firms are from regulated industries. One important reason for such a small proportion of connected firms from the regulated sector is the dominance of multinational firms in the telecom and petroleum sectors. As such, multinational firms are generally known to use their influence and political pressure in developing countries to change policies favorably instead of bringing politicians onto boards (Kapfer, 2006). Hence, considering a small set of connected firms from the regulated sectors, the separate treatment of the regulated sector is not necessary in our analysis and utilization of Indus_connection as an instrumental variable will not bias our results. In the second-stage analysis, the measures of political connection (Connected, Connected1, and Connected2) are replaced with the fitted value of political connections, obtained from the first-stage probit model. Results of the first-stage are shown in Table 5 and discussed in the previous section ('determinants of corporate political connections).

Table 6 shows the second-stage regression results of the Heckman two-stage model for firm leverage. The results in column (1) show that the estimated coefficient on Connected is positive and statistically significant at the $1 \%$ level. This result is consistent with Hypothesis 1 and suggests that, on average, politically connected firms have more leverage compared to nonconnected firms ${ }^{11}$. In terms of economic significance, a one standard deviation increase in political connection would lead to an increase in leverage by $7.04 \%$ (i.e., $(0.101 \times 0.46) / 0.66)$. Our empirical findings are consistent with Pan and Tian (2018), Ebrahim et al., (2014), Faccio (2006), Khwaja and Mian (2005), Dinç (2005) and Charumilind et al. (2006), all of whom illustrate the higher borrowing of connected firms. Firms with higher tangible assets, larger size, lower growth, and business group affiliation have, ceteris paribus, higher leverage. Firms

\footnotetext{
${ }^{10} \mathrm{We}$ are grateful to the referee for pointing this out.

${ }^{11} \mathrm{We}$ also conducted the regression analysis for the impact of a politician on short-term and long-term debt separately. Our results (untabulated) show a statistically insignificant impact of corporate political connections on short-term debt, whereas a positive and significant effect is found on long-term debt.
} 
belonging to basic industries (including petroleum), construction, and textile sectors utilize more leverage.

Next, in column (2) the coefficient of Connectedl is positive and significant implying that if a narrower definition of political connection (which captures politician winning effect) is used, we obtain a stronger association between connections and leverage. In terms of economic significance, results indicate that connections with winning politician would lead to an increase in leverage by $8 \%$. In column (3), the relation between Connected2 (party winning effect) and leverage is found to be positive and significant with an even larger economic significance of $9.4 \%$. The results show that the inverse Mills ratio $(\lambda)$ is significant in column (3) indicating the significance of controlling the self-selection bias in the analysis. Overall, these results support our contention that a winning politician and a politician belonging to a winning party confer even larger political benefits. Largely, our results validate the resourcebased perspective, which advocates the inclusion of directors with a political background as a means of bringing external resources to the organization. In this respect, the politically affiliated directors influence banks and other lending institutions to provide connected firms a privileged access to external finance.

\subsubsection{Excess cash holdings}

In this section, we test whether the connections have any effects on excess cash holdings. For our analysis, the choices of variables representing firm characteristics that may influence the cash holdings decision are based on the related literature, such as Dittmar et al. (2003), Ozkan and Ozkan (2004), Belghitar and Khan (2013) and Saeed et al. (2014). More specifically, the following control variables are employed for our reduced form regression: size, growth opportunities, net working capital, dividend payment, liabilities, business group affiliation, large-shareholders and board independence.

Firm size is used as a proxy for a takeover deterrent. At the same time firm size is also considered as an inverse proxy for information asymmetry and, in turn, the cost of external capital (Dittmar et al., 2003). Accordingly, large firms are more likely to hold less excess cash compared to smaller firms. A dummy variable is introduced to capture the effect of the dividend policy on cash holdings (Ozkan and Ozkan, 2004). Firms with growth opportunities prefer to retain their earnings as cash to avoid situations in which they give up profitable investment opportunities due to short of cash (Ozkan and Ozkan, 2004). The growth opportunities of firms are measured by the market-to-book ratio. Furthermore, firm net working capital is included in the model to control other essential financial characteristics of each firm. It is reasonable to 
presume that the conversion of non-cash liquid assets into cash is much easier and cheaper compared to other assets. Therefore, firms having a sufficient level of liquid assets may not have to turn to the external capital markets to raise finance when they have lower cash reserves. Net working capital can therefore be considered as a cash substitute. Earlier studies (e.g. Khanna and Palepu, 2000) documented that the business groups maintain an internal capital market to transfer resources among affiliated firms. This is particularly true in developing countries where business group affiliation is generally deemed as an antidote for market imperfections. Therefore, a variable, business group affiliation, is included in the model to control for the impact of group affiliation. Finally, large-shareholders, board-independence, and CEO duality are used as corporate governance mechanisms.

The regression results from the Heckman sample selection model are shown in Table 7 where Excess Cash is used as the dependent variable in the second stage. The R-square of the unreported regression results of equation (1) is $26 \%$ which indicates the explanatory power of the model as satisfactory. The explanatory power of our model is comparable to other studies conducted in the context of developed countries, for instance 25\% in Ozkan and Ozkan (2004); 19.1\% in Harford et al. (2008). In column (1), the results show that the coefficient on Connected is positive and significant. More specifically, it suggests that a one standard deviation increase in connections leads to an increase in excess cash of $5 \%$ (i.e. $(0.021 \times 0.46) / 0.19)$. Regarding the control variables, our results are very similar to Dittmar et al. (2003). Managers like to hold larger excess cash if the size of the firm is small, pays no dividend, maintains low liabilities and has fewer independent directors on their boards. Net working capital is not found to have a significant relationship with excess cash holdings. Firms belonging to consumer and services industries hold more cash, whereas textile sector firms hold less. The estimations provided in columns (2) with Connectedl and in column (3) with Connected2 show the positive and significant impact of political connections on the level of cash reverses. Economically, the party winning effect is larger than the politician winning effect ( $5.8 \%$ vs. $7.9 \%)$. Considering the economic significance, it can be suggested that politicians confer even more advantages to connected firms when they win the election or belong to the winning party. The results in Table 7 consistently show that political connections have a positive effect on excess cash reserves, supporting our Hypothesis 2, which asserts that connected firms hold more cash than their nonconnected peers.

The preferential access to external finance further exacerbates the tendency of connected firms to engage in stockpiling cash. Thus, it is not surprising to observe a complementary effect of connections on the amount of cash reserves. Our finding is in line 
with those of Boubakri et al. (2013), Kusnadi (2011), Saeed et al. (2014) and Dittmar et al. (2003), who show that firms with greater agency problems hold larger cash balances. Considering these arguments and earlier evidence, it is safe to conclude that higher excess cash holdings among connected firms signal the presence of agency problems.

\subsubsection{Accruals management}

In this section, we examine how much of the firm's abnormal accounting accruals can be attributed to political connections. We use the absolute value of abnormal accruals to assess managers' attempts to manipulate earnings in both directions. In robustness tests, we also employ the original value of accruals to confirm and contrast our findings with related studies. We evaluate the association between the political connections and accruals management after controlling for the impact of other relevant variables. The use of control variables, namely, size, leverage, volatility in sales, growth opportunities, large-shareholders, boardindependence and CEO duality is based on their relevance to accruals management and is in line with the earlier studies (e.g. Datta et al., 2013; Dejong and Ling, 2013, Park and Shin, 2004).

Table 8 presents the estimates of the Heckman selection model. In panel A, the dependent variable is absolute abnormal accruals (Abnormal Accruals). Column (1) reports the results of the regression of discretionary accruals on the indication of political connectedness and controls. The results for the entire sample show that the coefficient on Connected is positive and statistically significant confirming our hypothesis 3 ; indicating that politically connected firms are associated with a higher level of discretionary accruals, i.e. a lower quality of reported earnings ${ }^{12}$. The economic significance of these results can be interpreted as a one standard deviation increase in connections would lead to an increase of $3.98 \%$ in the absolute values of accruals. We re-estimate the regression with the dependent variable, original value of accruals. Findings for the original value of accruals are shown in panel B. In Panel B, the results show that political connections interact positively and significantly with the original values of accruals. The economic significance shows that a one standard deviation increase in connections leads to an increase in the original values of accruals by $3.8 \%$. The estimated coefficients on the control variables indicate that small, growing, and financially constrained firms engage more in discretionary accruals management. Regarding sectorial effects, construction and services industries exert negative and positive effects, respectively, on the

\footnotetext{
${ }^{12}$ Recall that a positive sign on Connected indicates that connected firms have greater incentives to manipulate earnings for political purposes, which in turn deteriorate the accruals quality.
} 
quality of reporting. These results are indicative of the agency problems and corroborate evidence in Xu et al, (2018); Kostovetsky (2015); Chaney et al. (2011) and Ben-Nasr et al. (2015), who find that the quality of the accruals of politically connected firms is poorer than that of non-connected firms.

Next, we turn to examine the impact of political strength of connected politicians. In columns (2) and (3), we observe positive and significant coefficients on Connectedl and Connected2, respectively. The economic significance of a winning politician (4.4\%) and a winning party (5.9\%) indicate that the earnings management decision is also driven in large part by the impact of politicians related to the ruling party. For the original value of accruals, we find that Connected 1 and Connected 2 exert a positive economic impact $(3.1 \%$ and $5.7 \%$, respectively). The significance level is low but results are qualitatively similar to the findings of absolute values.

Collectively, our results indicate that corporate political connections bring costs and benefits. On the one hand, we find that connected directors enhance the organizational resource base by providing more credit with longer maturity. On the other hand, political directors use their increased power to weaken corporate governance, leading to distortions in cash holdings and accruals management decisions. In sum, the appointment of a politician to a board is an important source of financial resources for a firm but these resources entail costs reflected in higher agency problems.

\subsection{Robustness checks}

\subsubsection{Alternative measures of dependent variables}

To ascertain that our results are not specific to the measures of financial policies (dependent variables) selected here, we repeat the regressions reported in Tables 6-8 with alternative measures of the dependent variables. More specifically, following John and Litov (2010), we use a market based value of leverage which is measured as the total debt divided by the market value of assets (equal to total assets minus book equity plus market value of equity). The cash holdings variable, akin to Chen et al. (2011), is proxied by free cash flow which is defined as cash flow from operations minus cash dividends and scaled by total assets instead of excess cash holdings. Lastly, we take the difference between firm's earnings and cash flows, as in Chava and Puranndum (2010), to measure the extent of the quality of financial reporting. We consult the cash flow statements to construct the accruals management variable. 
The results, as reported in Panel A of Table 9, show that political connections continue to be positively and significantly associated with all the new financial proxy measures. Further, the impact of political strength remains positive and statistically significant. Although the statistical significance tends to be low for capital structure and cash holdings, the results generally conform to those presented earlier. In sum, the results reinforce our basic inferences on the strong, significant effect of political connections on corporate financial decisions and indicate that our main results are robust to how financial policies are being measured.

\subsubsection{Inclusion of other measures of corporate governance}

The impact of political connections on a firm's financial policies could be reduced if the firms are externally scrutinized. In this regard, Boubakri et al. (2013) argue that the increased scrutiny associated with the analysts and foreign investors discourages politically connected directors from influencing financial decisions. Leuz and Oberholzer-Gee (2006) report that Indonesian politically affiliated firms are less inclined to access global capital markets because expanded disclosure and additional scrutiny come with foreign securities. In light of this, we use a dummy variable, Foreign Listing, that takes value 1 if the firm is listed abroad and 0 otherwise, to control the foreign listing status. To capture how impact of political connections on financial policies varies across foreign listed and unlisted firms, we introduce an interactive term (between foreign listing and measure of political connection) in the model. The results are displayed in Panel B of Table 9. The introduction of the interactive term does not significantly alter our earlier results. In each of the models, the value of political connections is statistically significant and has the expected sign. In addition, the estimated coefficients on Connected 1 and Connected 2 are statistically significant, similar in magnitude and have the same sign. The interactive term is negative and statistically significant only for leverage indicating that connected firms listed in foreign markets are less likely to increase their leverage as compared to their connected peers listed only in Pakistan. Altogether, the role of political connections is robust to the inclusion of additional variables of corporate governance.

\subsubsection{Alternative estimation techniques}

To further check the robustness of our estimated results two additional estimators are considered. First, to minimize the endogeneity concerns between firm policies and political connections, our empirical strategy is based on the cross-sectional approach, suggested by Rajan and Zingales (1995), Belghitar and Khan (2013), and Khwaja and Mian (2005). The cross-section technique involves regressing the financial variables on an average of the 
variables over time. More specifically, the cross-sectional model uses the dependent policy variables measured as of 2010, the average values of each of the firm's characteristics over the period 2002-2009 are used as independent variables. The results presented in Panel C of Table 9 confirm the previous findings. The positive relationship between political connections and financing policies remains statistically significant. Second, we use the random-effect model with both time and industry dummies that controls for industry heterogeneity and also controls for the effects of the time-invariant variables included in the model. In all regressions, presented in Panel C, our main results for political connections remain stable. Thus, we can conclude that our results are robust to alternative estimation techniques.

\section{Conclusion}

The present paper investigates the impact of political connections on corporate financial policy including capital structure, maturity structure, excess cash holdings, and accruals management. Using data on Pakistani firms from 2002 to 2010, our results show that political connections lead firms to utilize more leverage in their capital structure, hold larger excess cash balances and increase accruals management. The impact of political connections on corporate financial policy escalates with the strength of the connected politician. Importantly, we find that the winning party effect is more pronounced than the winning politician effect. The results are robust to alternative measures of financial policies, different sample selection, alternative estimation techniques and the inclusion of other measures of corporate governance.

Overall, we deduce two theoretical patterns from these results. First, politicians can bring external resources to the organization, which supports the resource-based view of political connections. Second, political connectedness undermines corporate governance and causes agency problems that are reflected in excess cash holdings and increased accruals management.

While our study is not aimed at resolving the debate about whether establishing political connections on board is necessary or even desirable, we do provide empirical evidence that political relationships do play an important role in the way firms make financial decisions. Although connections bring financial resources to a firm, they come at a cost to shareholders in the form of excess cash holdings and lower quality earnings reports.

It is important to mention that the focus on a single developing country enables us to ground the major theoretical construct that shapes the relationships of interest within a context. However, it limits us in generalizing the results to other settings as the corporate connectionpolicies nexus may reveal different strengths or directions in other contexts due to institutional 
stability, shareholders' protection, financial market development, and transparency standards across countries. 


\section{References}

Aggarwal R K, Meschke F, Wang T Y (2009) Corporate Political Contributions: Investment or Agency? University of Minnesota working paper.

Ahmed H, Javad A (2009) Dynamics and Determinants of Dividend Policy in Pakistan. Int Res $\mathrm{J}$ of Financ Econ 28: 56-61.

Ahsan T, Wang M, Qureshi M A (2016) Firm, industry, and country level determinants of capital structure: evidence from Pakistan. South Asian J Global Bus Res 5(3): 362-384.

Anwar Z, Afza T (2014) Impact of terrorism, gas shortage and political instability on FDI inflows in Pakistan. Scientific Int 26(1): 507-511.

Anagnostopoulou S C (2013) Cash Holdings: Determining Factors and Impact on Future Operating Performance for Listed versus Unlisted Firms. Rev Pac Basin Financ Mark Pol 16(2): 1-47.

Ashraf J, Ghani W (2005) Accounting development in Pakistan. Int J Acc 40: 175-201.

Batta G E, Heredia R S, Weidenmier W (2014) Political connections and accounting quality under high expropriation risk. European Acc Rev 23(4): 485-517.

Belghitar Y, Khan J (2013) Governance mechanisms, investment opportunity set and SMEs cash holdings. Small Bus Econ 40(1): 59-72.

Belghitar Y, Clark E (2014) The Effect of Option Based Managerial Compensation on Corporate Cash Holdings, J Financ Res 37 (2): 191-210

Ben-Nasr H, Boubakri N, Cosset J C (2015) Earnings Quality in Privatized Firms: The Role of State and foreign owners. J Acc Public Policy 34: 392-416.

Berger P, Ofek E, Yermack D (1997) Managerial entrenchment and capital structure decisions. J Financ 52, 1411-1438.

Bertrand M, Kramarz F, Schoar A, Thesmar D (2018) The cost of political connections. Rev Financ 22(3): 849-876.

Boubakri N, Ghoul S E, Saffar W (2013) Cash holdings of politically connected firms. J Multinational Financ Manage 23: 338-355.

Boubakri N, Cosset J, Walid S (2008). Political connections of newly privatized firms. J Corp Financ 14: 654-673.

Brick I E, Ravid A S (1985) On the relevance of debt maturity structure. J Financ 40 (5): 14231437.

Bunkanwanicha P, Wiwattanakantang Y (2009) Big business owners in politics. Rev Financ Stud 22(6): 2133-2168.

Calf J L (1994) The relationship between firm size and export behavior revisited. J Int Bus Stud 25(2): 367-387.

Campbell J Y (1996) Understanding risk and return. J Pol Econ 104(2): 298-345.

Chaney P, Faccio M, Parsley D (2011) The quality of accounting information in politically connected firms. J Acc Econ 51: 58-76.

Charumilind C, Kali R, Wiwattanakantang Y (2006) Connected lending: Thailand before the financial crisis. J Bus 79(1): 181-218.

Chava S, Purnanandam A (2010) CEOs versus CFOs: incentives and corporate policies. J Financ Econ 97: 263-278. 
Chen K C W, Chen Z, Wei K C J (2011) Agency costs of free cash flow and the effect of shareholder rights on the implied cost of equity capital. J Financ Quant Anal, 46: 171-207.

Chen L, Zhao X (2006) On the relation between the market-to-book ratio, growth opportunity, and leverage ratio. Financ Res Lett 3(4): 253-266.

Claessens S, Feijen E, Laeven L (2008) Political connections and preferential access to finance: The role of campaign contributions. J Financ Econ 88(3): 554-580.

Dang C, Li Z F, Yang C (2018) Measuring firm size in empirical corporate finance. J Bank Financ 86(1): 159-176.

Datta S, Datta M, Singh V (2013) Product market power, industry structure, and corporate earnings management. J Bank Financ 37(8): 3273-3285.

Dejong D, Ling Z (2013) Managers: Their effects on accruals and firm policies. J Bus Financ Acc 40(1-2): 82-114.

Desai R M, Olofsgard A (2011) The Costs of Political Influence: Firm-Level Evidence from Developing Countries. Q J Pol Sci. 6: 137-178.

Dinç I S (2005) Politicians and banks: Political influences on government-owned banks in emerging markets J Financ Econ 77(2): 453-79.

Ding S, Jia C, Wilson C, Wu Z (2015). Political connections and agency conflicts: the roles of owner and manager political influence on executive compensation. Rev Quant Financ Acc 45(2): 407-434.

Dittmar A, Mahrt-Smith J (2007) Corporate governance and the value of cash holdings. J Financ Econ 83: 599-634.

Dittmar A, Mahrt-Smith J, Servaes H (2003) International corporate governance and corporate cash holdings. J Financ Quant Anal, 38, 111-133.

Ebrahim M S, Girma S, Shah E M, Williams J (2014) Dynamic capital structure and political patronage: The case of Malaysia. Int Rev Financ Anal 31: 117-128.

Faccio M (2006) Politically connected firms. American Economic Review, 96(1), 369-386.

Faccio M (2010) Differences between politically connected and non-connected firms: A cross country comparison. Financ Manage 39, 905-927.

Fan J P H, Oliver M R, Zhao M (2008) Public governance and corporate finance: Evidence from corruption cases. J Comp Econ 36(3): 343-364.

Ferris S P, Houston R, Javakhadze D (2016) Friends in the right places: The effect of political connections on corporate merger activity. J Corp Financ 41: 81-2012.

Frank M Z, Goyal V (2009) Capital structure decisions: Which factors are reliably important? Financ Manage 38(1): 1-37.

Frank M Z, Goyal V (2005) Trade-Off and Pecking Order Theories of debt. In Handbook of Empirical Corporate Finance. Vol. 2. Chapter 12, Pages 135-202.

Fraser D R, Zhang H, Derashid C (2006) Capital structure and political patronage: the case of Malaysia. J Bank Financ 30(4): 1291-1308.

Godfrey P (2005) The relationship between corporate philanthropy and shareholder wealth: a risk management perspective. Acad Manage Rev 30(4): 777-798.

Hameed S A, Tariq Y B, Jadoon I A (2013) Corporate Governance in Financial Sector Companies of Pakistan: Current State and Room for Improvement. World Applied Sci J 21(1): 79-92. 
Harford J, Mansi S A, Maxwell W F (2008) Corporate governance and firm cash holdings in the US. J Financ Econ 87(3): 535-555.

Hazarika S, Karpoff J M, Nahata R (2012) Internal corporate governance, CEO turnover, and earnings management. J Financ Econ 104: 44-69.

Heckman J (1979) Sample selection bias as a specification error. Econometrica, 47, 153-161.

Hill M D, Fuller K P, Kelly G W, Washam J O (2014) Corporate cash holdings and political connections. Rev Quant Financ Acc 42(1): 123-142.

Husain I (2012) Governor of the State Bank of Pakistan, reproduced from Blue Chip. The Business People's Magazine.

Infante L, Piazza M (2010) Do political connections pay off? Some evidences from the Italian credit market, Bank of Italy, Economics, Research and International Relations Area Working Paper Series.

International Business Promotion (2015) Pakistan: Doing Business and Investing in Pakistan: Strategic, Practical Information, Regulations, Contacts, World Business and Investment Library, Publisher Lulu.com, ISBN: 1514527472.

International Monitory Fund (2016) Bank non-performing loans to total gross loans \%, http://data.worldbank.org/indicator/FB.AST.NPER.ZS?locations=PK [last accessed 21 April, 2017]

Jamal N (2015) Need for a bankruptcy law. Dawn, https://www.dawn.com/news/1206770 [last accessed 15 April 2017]

Javid A (2010) Corporate governance in Pakistan: Corporate valuation, ownership and financing. Pakistan Institute of Development Economics Working Paper 2010:57.

Javorcik B S, Spatareanu M (2011) Does it matter where you come from? Vertical spillovers from foreign direct investment and the origin of investors. J Develop Econ 96(1): 126-138.

Jensen M (1986) Agency costs of free cash flow, corporate finance and takeovers. Am Econ Rev 76: 323-329.

Jiraporn P, Chintrakrn P, Liu Y (2012) Capital Structure, CEO Dominance, and Corporate Performance. J Financ Serv Res, 42(3), 139-158.

John K, Litov L (2010) Corporate governance and financing policy: New evidence. In: AFA 2006 Boston Meetings.

Kapfer S (2006) Multinational Corporations and the Erosion of State Sovereignty. Paper prepared for Illinois State University Illinois State University Conference, Illinois State University, https://pol.illinoisstate.edu/downloads/conferences/2006/Kapfer2006.pdf

Khan A, Mihret D G, Muttakin M B (2016) Corporate political connections, agency costs and audit quality. Int J Acc Inform Manage 24(4): 357-374.

Khan W M (2018) SBP autonomy and monetary policy - V, Business Recorder, $7^{\text {th }}$ February 2018, https://fp.brecorder.com/2018/02/20180207341694/ [last accessed: 01-05-2018]

Khanna T, Palepu K (2000) The future of business groups in emerging markets: Long-run evidence from Chile. Acad Manage J 43(3): 268-285.

Khwaja A I, Mian A R (2005) Do lenders favor politically connected firms? Rent provision in an emerging financial market. Q J Econ 120(4): 1371-1411.

Kimura F, Kiyota K (2007) Foreign-Owned versus Domestically-Owned Firms: Economic performance in Japan. Rev Dev Econ 11(1): 31-48.

Kostovetsky, L. (2015), Political capital and moral hazard, J Financ Econ 116(1): 144-159. 
Kothari, S., Leone, A. and Wasley, C., 2005. Performance-matched discretionary accrual measures. J Acc Econ 39: 163-197.

Kundi I (2017) Tariq Bajwa new SBP governor amid autonomy concerns. The Nation, 08 July, 2017 https://nation.com.pk/08-Jul-2017/tariq-bajwa-new-sbp-governor-amid-autonomyconcerns [last accessed: 24-04-2018]

Kusnadi Y (2011) Do corporate governance mechanisms matter for cash holdings and firm value? Pacific-Basin Financ J 19(5): 554-570.

Lee W, Wang L (2017) Do political connections affect stock price crash risk? Firm-level evidence from China. Rev Quant Financ Acc 48(3): 643-676.

Leuz C, Oberholzer-Gee F (2006) Political relationships, global financing, and corporate transparency: Evidence from Indonesia. J Financ Econ 81(2): 411-439.

Myers S C, Majluf N S (1984) Corporate financing and investment decisions when firms have information that investors do not have. J Financ Econ 13(2): 187-221.

Modigliani F, Miller M H (1958) The cost of capital, corporate finance and the theory of investment. American Econ Rev 48: 261-297.

Moosa I, Li L (2012) Firm-specific factors as determinants of capital structure: evidence from Indonesia. Rev Pac Basin Financ Mark Pol 15: 1150007-1150017.

Muttakin M B, Monem R M, Khan A, Subramaniam N (2015) Family firms, firm performance and political connections: Evidence from Bangladesh. J Cont Acc Econ 11(3): 215-230.

Myers S (1977) Determinants of corporate borrowings. J Financ Econ 5: 147-175.

Naeem S, Nasr M (2007) Dividend policy of Pakistani firms; trends and determinants. Int Rev Bus Res 3(3): 242-254.

Oberman W D (2004) A framework for the ethical analysis of corporate political activity. Bus Society Rev 109: 245-262.

Opler T, Pinkowitz L, Stulz R, Williamson R (1999) The determinants and implications of cash Holdings. J Financ Econ 52: 3-46.

Ozkan A, Ozkan N (2004) Corporate cash holdings: An empirical investigation of UK companies. J Bank Financ 28: 2103-2134.

Pan X, Tian G G (2018) Bank work experience versus political connections: Which matters for bank loan financing. Int Rev Financ https://doi.org/10.1111/irfi.12225

Park Y W, Shin H H (2004) Board composition and earnings management in Canada. J Corp Financ 10: 431-457.

Petersen M A (2009) Estimating Standard Errors in Finance Panel Data Sets: Comparing Approaches. Rev Financ Stud 22:435-80.

Rajan R G, Zingales L (1995) What do we know about capital structure? Some evidence from International data. J Financ 50(5): 1421-1460.

Rehman U R (2006) Who owns Pakistan. 5th Edition, Islamabad: Mr. Books (Pvt.) Ltd.

Saeed A, Belghitar Y, Clark E (2015) Political connections and firm leverage: Firm level evidence from Pakistan. Manage Decision Econ 36(6): 364-383.

Saeed, A, Belghitar Y, Clark E (2014) Theoretical motives of corporate cash holdings and political connections: Firms level evidence from a developing economy, Int Rev Appl Econ, 28(6): 813-831.

Scherr F C, Hulburt H M (2001) The debt maturity structure of small firms. Financ Manage 30: 85-111. 
Shah, S.H., Ahmad, M.H., Ahmed, Q.M. (2016) The nexus between sectoral FDI and institutional quality: Empirical evidence from Pakistan. Appl Econ 48(17): 1591-1601.

Shakeel, A. (2018) The state of Pakistani democracy. Berkley Political Review, March 7, 2018, https://bpr.berkeley.edu/2018/03/07/the-state-of-pakistani-democracy/

Shen C, Lin C (2016) Political connections, financial constraints, and corporate investment. Rev Quant Financ Acc 47(2): 343-368.

Singh, M., \& Davidson III, W. (2002) Agency costs, ownership structure and corporate governance mechanisms. J Bank Finan 27: 793-816.

$\mathrm{Su}, \mathrm{Z}$. and Fung, H. (2013) Political connections and firm performance in Chinese companies. Pacific Econ Rev 18: 283-317.

State Bank of Pakistan, 2017, Statistics on Scheduled Banks in Pakistan, http://www.sbp.org.pk/publications/schedule banks/Dec-11.htm [last accessed 26 April 2018]

Stevenson, M. (2003) UN Countries Reveal Costs of Corruption. Global Policy Forum. (http://www.globalpolicy.org)

$\mathrm{Xu} \mathrm{H}$, Dao M, Wu J (2018) The effect of local political corruption on earnings quality. Rev Quant Finan Acc. https://doi.org/10.1007/s11156-018-0758-X

Wang, D., Ma,G., Song, X. and Liu, Y. (2016) Political connection and business transformation in family firms: Evidence from China. J Family Bus Strateg 7(2): 117-130.

Walsh, E.J. and Ryan, J., (1997) Agency and tax explanations of security issuance decisions. J Bus Financ Acc 24(7/8): 943-61.

Wernerfelt, B. 1984. A resource-based view of the firm, Strategic Manage J 5: 171-180.

World Justice Project, (2016) WJP Rule of law Index-2016, https://worldjusticeproject.org/our-work/wjp-rule-law-index/wjp-rule-law-index-2016 [last accessed 28 April 2017]

Wu, W., C. Wu and O. M. Rui (2012) Ownership and the value of political connections: Evidence from China, European Financ Manage 18: 695-729.

Zaheer, F. (2016) FDI in Pakistan down massive $45 \%$ in Jul-Nov, Tribune, https://tribune.com.pk/story/1264614/fdi-pakistan-massive-45-jul-nov/ [last access: 1st May 2017]

Zwiebel, J., (1994) Dynamic capital structure under managerial entrenchment. Working paper, Graduate School of Business, Stanford University. 


\begin{tabular}{|c|c|c|c|c|c|c|}
\hline \multicolumn{7}{|c|}{ A. Distribution of sample } \\
\hline & \multicolumn{2}{|c|}{ Total sample } & \multicolumn{2}{|c|}{ Connected firms } & \multicolumn{2}{|c|}{ Non-connected firms } \\
\hline & \# & $\%$ & \# & $\%$ & \# & $\%$ \\
\hline Total number of firms & 403 & 100 & 116 & 28.78 & 287 & 71.21 \\
\hline Group-affiliates & 114 & 28.28 & 64 & 55.17 & 50 & 17.42 \\
\hline Stand-alone & 289 & 71.72 & 52 & 44.83 & 237 & 82.58 \\
\hline Foreign owned & 42 & 10.42 & 9 & 7.75 & 33 & 11.49 \\
\hline \multirow[t]{2}{*}{ Domestic owned } & 361 & 89.58 & 107 & 92.25 & 254 & 88.51 \\
\hline & \multicolumn{6}{|c|}{ B. Distribution of politically connected firms by electoral outcomes } \\
\hline \multirow[b]{2}{*}{ Connected to winner } & \# & $\%$ & & & & \\
\hline & 67 & 57.75 & & & & \\
\hline Connected to looser & 49 & 42.25 & & & & \\
\hline Connected to winning party & 81 & 69.82 & & & & \\
\hline Connected to opposition party & 35 & 30.18 & & & & \\
\hline \multicolumn{7}{|c|}{ C. Distribution of sample across industries } \\
\hline & \multicolumn{2}{|c|}{ Total sample } & \multicolumn{2}{|c|}{ Connected firms } & \multicolumn{2}{|c|}{ Non-connected firms } \\
\hline & $\#$ & $\%$ & \# & $\%$ & $\#$ & $\%$ \\
\hline Food \& Tobacco & 48 & 11.91 & $11^{\phi}$ & 9.48 & 37 & 12.89 \\
\hline $\begin{array}{l}\text { Basic industries including } \\
\text { petroleum }\end{array}$ & 67 & 16.63 & $17^{\phi \phi}$ & 14.66 & 50 & 17.42 \\
\hline Construction & 61 & 15.14 & 18 & 15.52 & 43 & 14.98 \\
\hline Textiles \& Trade & 146 & 36.23 & 39 & 33.62 & 107 & 37.28 \\
\hline Consumer durables & 33 & 8.19 & 12 & 10.34 & 21 & 7.32 \\
\hline Transportation & 16 & 3.97 & 8 & 6.90 & 8 & 2.79 \\
\hline Services (telecom) & 11 & 2.73 & $4^{\phi \phi \phi}$ & 3.45 & 7 & 2.44 \\
\hline Others & 21 & 5.21 & 7 & 6.03 & 14 & 4.88 \\
\hline
\end{tabular}

$\phi$ Among these 11 connected firms, 1 firm belongs to tobacco sector, remaining 10 belongs to food industries. $\phi \phi 5$ firms belong to petroleum sector, rest 12 are from basic industries. $\phi \phi \phi 2$ firms belong to telecom sector and 1 from power sector. 
Table 2: Variables definitions

\begin{tabular}{|c|c|}
\hline Variables & Definition \\
\hline Connected & $\begin{array}{l}\text { A firm is defined as connected if it has a politician on its Board of } \\
\text { Directors. A politician is defined as any individual who stood in } \\
\text { the national or provincial elections. }\end{array}$ \\
\hline Connected 1 & $\begin{array}{l}\text { A dummy variable that equals one if the connected politician wins } \\
\text { the election and zero if otherwise }\end{array}$ \\
\hline Connected2 & $\begin{array}{l}\text { A dummy that equals one if the connected politician is a member } \\
\text { of ruling party and zero otherwise. }\end{array}$ \\
\hline Leverage & $\begin{array}{l}\text { The book value of a firm's total debt (short-term and long-term) to } \\
\text { the total assets }\end{array}$ \\
\hline Long-term Debt & Long-term debt divided by its total debt. \\
\hline Excess Cash & Obtained from equation 2 residuals. \\
\hline Abnormal accruals & Absolute value of abnormal accruals. \\
\hline Firm Size & $\begin{array}{l}\text { Natural logarithm of the annual sales revenue (total sale) of the } \\
\text { firm. }\end{array}$ \\
\hline Tangible Assets & Fraction of fixed assets to total assets. \\
\hline Profitability & $\begin{array}{l}\text { Profitability is measured as income before taxes divided by total } \\
\text { assets. }\end{array}$ \\
\hline Growth Opportunities & $\begin{array}{l}\text { The market-to-book ratio calculated as the market value of equity } \\
\text { plus the book value of liabilities divided by the book value of total } \\
\text { assets. }\end{array}$ \\
\hline Foreign Ownership & $\begin{array}{l}\text { A dummy variable that equals one if at least } 10 \% \text { of its stock is } \\
\text { foreign owned and zero if otherwise. }\end{array}$ \\
\hline Business Group Affiliation & $\begin{array}{l}\text { A dummy variable that equals one if the firm belongs to a business } \\
\text { group and zero if otherwise. }\end{array}$ \\
\hline Firm Quality & $\begin{array}{l}\text { The difference between earnings per share } \mathrm{t}+1 \text { and } \mathrm{t} \text {, divided by } \\
\text { share price in year } \mathrm{t} \text {. }\end{array}$ \\
\hline Tax Rate & The ratio of total tax charge to total taxable income \\
\hline Liabilities & $\begin{array}{l}\text { Total liability divided by total assets, where total liability includes } \\
\text { both financial and operational liabilities. Liabilities include both } \\
\text { interest-bearing and non-interest-bearing liabilities. Non-interest } \\
\text { bearing liabilities include accounts payable, salary payable, taxes } \\
\text { payable/deferred taxes, other contractual liabilities, and accruals } \\
\text { (accrued income taxes, other expenses accrued but unpaid). }\end{array}$ \\
\hline Dividend payment & $\begin{array}{l}\text { A dummy variable that equals one if firm pays dividend in a } \\
\text { current year and zero otherwise. }\end{array}$ \\
\hline Net Working Capital & Working capital minus cash divided by net assets. \\
\hline Large Shareholders \% & The percentage of shares held by the largest shareholders. \\
\hline Board Independence & $\begin{array}{l}\text { The ratio of independent directors divided by total number of } \\
\text { directors. }\end{array}$ \\
\hline
\end{tabular}


Table 3: Summary statistics of variables

\begin{tabular}{|c|c|c|c|c|c|c|c|c|c|c|c|c|c|}
\hline & & Total & ample & & Connect & d firms & & & Non-con & ected firm & & & Mean difference \\
\hline & Mean & St. Dev & Min & $\operatorname{Max}$ & Mean & St. Dev & Min & $\operatorname{Max}$ & Mean & St. Dev & Min & $\operatorname{Max}$ & (t-statistics) \\
\hline Cash & 286,162 & 601,539 & 3064 & 2106,094 & 294,083 & 577,005 & 3867 & 2106,094 & 281,590 & 630,058 & 3064 & 2099,570 & $-4.09 * * *$ \\
\hline Total Accruals & 0.19 & 0.25 & 0.04 & 0.31 & 0.21 & 0.23 & 0.04 & 0.31 & 0.17 & 0.24 & 0.05 & 0.30 & $-1.61 * * *$ \\
\hline Leverage & 0.66 & 0.26 & 0.22 & 1.26 & 0.68 & 0.24 & 0.22 & 1.26 & 0.63 & 0.25 & 0.22 & 1.23 & $-3.31 * * *$ \\
\hline Long-term Debt & 0.39 & 0.31 & 0.01 & 1.00 & 0.42 & 0.32 & 0.01 & 1.00 & 0.38 & 0.31 & 0.01 & 1.00 & $-1.99 * * *$ \\
\hline Excess Cash & 0.19 & 0.30 & 0.01 & 0.45 & 0.17 & 0.40 & 0.01 & 0.45 & 0.11 & 0.25 & 0.02 & 0.39 & $-6.01 * * *$ \\
\hline Absolute Accruals & 0.59 & 0.45 & 0.02 & 0.78 & 0.60 & 0.44 & 0.03 & 0.78 & 0.58 & 0.48 & 0.02 & 0.77 & $-1.39 * * *$ \\
\hline Firm Size & 6.32 & 0.64 & 5.11 & 7.51 & 6.36 & 0.63 & 5.15 & 7.44 & 6.30 & 0.66 & 5.11 & 7.51 & $-1.56^{*}$ \\
\hline Tangible Assets & 0.51 & 0.20 & 0.09 & 0.85 & 0.50 & 0.21 & 0.09 & 0.84 & 0.49 & 0.21 & 0.12 & 0.85 & -0.72 \\
\hline Profitability & 5.89 & 10.88 & -13.76 & 12.31 & 4.41 & 10.31 & -13.50 & 12.31 & 6.67 & 11.09 & -13.76 & 11.85 & $4.59 * * *$ \\
\hline Growth Opportunities & 8.14 & 5.79 & 1.05 & 11.46 & 8.29 & 5.90 & 1.05 & 11.46 & 8.12 & 5.74 & 0.98 & 10.21 & -0.61 \\
\hline Foreign Ownership & 0.12 & 0.35 & 0 & 1 & 0.10 & 0.30 & 0 & 1 & 0.16 & 0.37 & 0 & 1 & $3.26 * * *$ \\
\hline Firm Quality & 0.03 & 0.42 & -7.68 & 16.05 & 0.03 & 0.41 & -7.68 & 16.05 & 0.03 & 0.42 & -7.53 & 15.99 & 0.30 \\
\hline Tax Rate & 0.21 & 0.14 & 0.01 & 0.53 & 0.20 & 0.13 & 0.01 & 0.46 & 0.22 & 0.15 & 0.02 & 0.53 & 0.64 \\
\hline Liabilities & 1.08 & 0.50 & 0.45 & 1.39 & 1.13 & 0.61 & 0.46 & 1.39 & 1.01 & 0.55 & 0.45 & 1.37 & $-3.01 * *$ \\
\hline Dividend Payment & 0.13 & 0.19 & 0.00 & 0.25 & 0.11 & 0.15 & 0.00 & 0.22 & 0.14 & 0.18 & 0.00 & 0.25 & 0.36 \\
\hline Net Working Capital & 0.06 & 0.04 & 0.02 & 0.21 & 0.05 & 0.02 & 0.02 & 0.21 & 0.08 & 0.06 & 0.02 & 0.19 & 1.21 \\
\hline Large Shareholders (\%) & 0.30 & 0.07 & 0.01 & 0.82 & 0.34 & 0.08 & 0.01 & 0.79 & 0.27 & 0.06 & 0.01 & 0.82 & -1.54 \\
\hline Board Independence & 0.36 & 0.04 & 0.19 & 0.67 & 0.36 & 0.04 & 0.19 & 0.64 & 0.39 & 0.03 & 0.21 & 0.67 & 0.13 \\
\hline
\end{tabular}

The mean and standard deviation of political connection variables are as follows: Connected: 0.31 and 0.46; Connected1: 0.18 and 0.41 ; and Connected2: 0.25 and 0.43 .

The definition of all variables is provided in Table 2 . 
Table 4: Correlation matrix

\begin{tabular}{|c|c|c|c|c|c|c|c|c|c|c|c|c|c|c|c|c|c|c|c|c|c|}
\hline & 1 & 2 & 3 & 4 & 5 & 6 & 7 & 8 & 9 & 10 & 11 & 12 & 13 & 14 & 15 & 16 & 17 & 18 & 19 & 20 & 21 \\
\hline 1. Connected & 1 & & & & & & & & & & & & & & & & & & & & \\
\hline 2. Connected 1 & 0.71 & 1 & & & & & & & & & & & & & & & & & & & \\
\hline 3. Connected 2 & 0.79 & 0.63 & 1 & & & & & & & & & & & & & & & & & & \\
\hline 4. Cash & 0.25 & 0.20 & 0.18 & 1 & & & & & & & & & & & & & & & & & \\
\hline 5. Total Accruals & 0.16 & 0.29 & 0.32 & -0.14 & 1 & & & & & & & & & & & & & & & & \\
\hline 6. Leverage & 0.51 & 0.56 & 0.41 & -0.21 & 0.02 & 1 & & & & & & & & & & & & & & & \\
\hline 7. Long-term Debt & 0.44 & 0.49 & 0.58 & -0.19 & 0.01 & 0.38 & 1 & & & & & & & & & & & & & & \\
\hline 8. Excess Cash & 0.29 & 0.27 & 0.33 & 0.38 & 0.14 & 0.11 & 0.09 & 1 & & & & & & & & & & & & & \\
\hline 9. Abnormal Accruals & 0.20 & 0.17 & 0.34 & -0.09 & 0.28 & 0.02 & 0.01 & 0.23 & 1 & & & & & & & & & & & & \\
\hline 10. Firm Size & 0.41 & 0.39 & 0.37 & 0.30 & 0.22 & 0.50 & 0.35 & 0.12 & 0.19 & 1 & & & & & & & & & & & \\
\hline 11. Tangible Assets & 0.21 & 0.23 & 0.26 & 0.18 & 0.11 & 0.36 & 0.40 & 0.06 & 0.11 & 0.44 & 1 & & & & & & & & & & \\
\hline 12. Profitability & 0.13 & 0.14 & 0.16 & 0.41 & 0.03 & -0.28 & -0.24 & 0.25 & 0.26 & 0.39 & 0.30 & 1 & & & & & & & & & \\
\hline 13. Growth Opportunities & 0.09 & 0.15 & 0.21 & 0.30 & 0.15 & 0.18 & 0.15 & 0.19 & 0.10 & 0.26 & 0.23 & 0.31 & 1 & & & & & & & & \\
\hline 14. Foreign Ownership & -0.01 & -0.00 & -0.00 & 0.04 & -0.23 & 0.15 & 0.01 & 0.03 & -0.02 & 0.33 & 0.29 & 0.25 & 0.19 & 1 & & & & & & & \\
\hline 15. Business Group Affiliation & 0.12 & 0.11 & 0.14 & 0.15 & 0.01 & 0.21 & 0.27 & 0.12 & 0.27 & 0.20 & 0.15 & 0.42 & 0.33 & -0.14 & 1 & & & & & & \\
\hline 16. Firm Quality & 0.10 & 0.07 & 0.12 & 0.12 & -0.04 & 0.10 & 0.05 & -0.08 & 0.01 & 0.11 & 0.18 & 0.26 & 0.02 & 0.10 & 0.18 & 1 & & & & & \\
\hline 17. Tax Rate & 0.03 & 0.02 & 0.00 & -0.06 & -0.01 & 0.19 & 0.24 & 0.01 & 0.13 & 0.25 & 0.01 & 0.19 & -0.15 & 0.30 & 0.12 & -0.09 & 1 & & & & \\
\hline 18. Liabilities & 0.36 & 0.43 & 0.34 & -0.18 & -0.19 & 0.47 & 0.39 & -0.02 & -0.15 & 0.38 & 0.41 & -0.21 & 0.12 & -0.13 & 0.25 & -0.10 & 0.20 & 1 & & & \\
\hline 19. Dividend Payment & 0.15 & 0.14 & 0.10 & -0.32 & 0.02 & -0.05 & -0.01 & -0.19 & -0.21 & 0.17 & 0.10 & 0.14 & 0.20 & 0.09 & 0.10 & -0.12 & -0.15 & -0.21 & 1 & & \\
\hline 20. Net Working Capital & 0.12 & 0.11 & 0.10 & 0.25 & 0.05 & 0.11 & 0.14 & -0.25 & 0.26 & 0.20 & 0.22 & 0.17 & 0.10 & 0.10 & 0.16 & 0.03 & 0.11 & -0.03 & 0.10 & 1 & \\
\hline 21. Large Shareholders (\%) & 0.08 & 0.07 & 0.16 & 0.17 & -0.22 & 0.13 & 0.11 & 0.01 & -0.19 & 0.29 & 0.35 & 0.15 & 0.09 & -0.11 & 0.20 & 0.26 & -0.00 & 0.17 & 0.25 & 0.16 & 1 \\
\hline 22. Board Independence & -0.16 & -0.19 & -0.27 & -0.26 & -0.14 & 0.10 & 0.17 & 0.20 & -0.31 & 0.15 & 0.24 & 0.38 & 0.18 & 0.27 & -0.03 & 0.21 & 0.01 & 0.20 & 0.19 & 0.11 & 0.24 \\
\hline
\end{tabular}


Table 5: Determinants of corporate political connections

This table presents the probit model estimates. The dependent variable is political connections which is one of the three political connections indicators (connected, connected1, and connected2). Standard errors are reported in brackets. *Significant at $10 \% * *$ Significant at $5 \% * * *$ Significant at $1 \%$.

\begin{tabular}{|c|c|c|c|}
\hline Variables & Connected & Connected 1 & Connected 2 \\
\hline \multirow[t]{2}{*}{ Firm Size } & $0.290 * * *$ & $0.315 * * *$ & $0.301 * * *$ \\
\hline & $(0.041)$ & $(0.060)$ & $(0.036)$ \\
\hline \multirow[t]{2}{*}{ Profitability } & $-0.043 * * *$ & $-0.041 * * *$ & $-0.041 * * *$ \\
\hline & $(0.005)$ & $(0.008)$ & $(0.012)$ \\
\hline \multirow[t]{2}{*}{ Tangible Assets } & 0.055 & 0.069 & 0.060 \\
\hline & $(0.246)$ & $(0.178)$ & $(0.140)$ \\
\hline \multirow[t]{2}{*}{ Growth Opportunities } & -0.110 & -0.080 & -0.094 \\
\hline & $(0.416)$ & $(0.216)$ & $(0.239)$ \\
\hline \multirow[t]{2}{*}{ Foreign Ownership } & 0.018 & 0.014 & 0.017 \\
\hline & $(0.053)$ & $(0.025)$ & $(0.049)$ \\
\hline \multirow[t]{2}{*}{ Business Group Affiliation } & $0.022 * * *$ & $0.021 * * *$ & $0.019 * * *$ \\
\hline & $(0.005)$ & $(0.003)$ & $(0.002)$ \\
\hline \multirow[t]{2}{*}{ Firm Quality } & -0.020 & -0.018 & -0.018 \\
\hline & $(0.073)$ & $(0.059)$ & $(0.040)$ \\
\hline \multirow[t]{2}{*}{ Tax Rate } & 0.011 & 0.008 & 0.013 \\
\hline & $(0.025)$ & $(0.019)$ & $(0.051)$ \\
\hline \multirow[t]{2}{*}{ Liabilities } & $1.075 * * *$ & $1.060 * * *$ & $1.114 * * *$ \\
\hline & $(0.160)$ & $(0.205)$ & $(0.176)$ \\
\hline \multirow[t]{2}{*}{ Dividend Payment } & $-0.026^{* * *}$ & $-0.024 * * *$ & $-0.025 * * *$ \\
\hline & $(0.005)$ & $(0.005)$ & $(0.004)$ \\
\hline \multirow[t]{2}{*}{ Net Working Capital } & 2.137 & 1.991 & 2.014 \\
\hline & $(4.508)$ & $(5.471)$ & $(3.753)$ \\
\hline \multirow[t]{2}{*}{ Large Shareholders } & $0.050 * * *$ & $0.051 * * *$ & $0.055 * * *$ \\
\hline & $(0.009)$ & $(0.013)$ & $(0.010)$ \\
\hline \multirow[t]{2}{*}{ CEO Duality } & 0.006 & 0.006 & 0.004 \\
\hline & $(0.014)$ & $(0.024)$ & $(0.019)$ \\
\hline \multirow[t]{2}{*}{ Indus_Connection } & $0.109 * * *$ & $0.095 * * *$ & $0.101 * * *$ \\
\hline & $(0.023)$ & $(0.015)$ & $(0.021)$ \\
\hline Year dummies & Yes & Yes & Yes \\
\hline \multirow[t]{2}{*}{ Ind_Food } & -0.535 & -0.580 & -0.501 \\
\hline & $(1.610)$ & $(2.004)$ & $(2.056)$ \\
\hline \multirow[t]{2}{*}{ Ind_Basic } & 0.345 & 0.402 & 0.368 \\
\hline & $(0.832)$ & $(1.125)$ & $(0.987)$ \\
\hline \multirow[t]{2}{*}{ Ind_Const } & $0.239 * * *$ & $0.265 * * *$ & $0.251 * * *$ \\
\hline & $(0.025)$ & $(0.055)$ & $(0.039)$ \\
\hline \multirow[t]{2}{*}{ Ind_Textile } & $0.517 * * *$ & $0.502 * * *$ & $0.534 * * *$ \\
\hline & $(0.049)$ & $(0.038)$ & $(0.034)$ \\
\hline \multirow[t]{2}{*}{ Ind_Consumer } & -0.071 & -0.063 & -0.076 \\
\hline & $(0.243)$ & $(0.307)$ & $(0.220)$ \\
\hline \multirow[t]{2}{*}{ Ind_Transp } & $0.190 * * *$ & $0.185^{* * *}$ & $0.192 * * *$ \\
\hline & $(0.022)$ & $(0.017)$ & $(0.015)$ \\
\hline \multirow[t]{2}{*}{ Ind_Services } & -1.043 & -1.050 & -1.036 \\
\hline & $(6.782)$ & $(7.041)$ & $(5.302)$ \\
\hline $\mathrm{N}$ & 2328 & 2328 & 2328 \\
\hline Pseudo R-square & 0.22 & 0.18 & 0.20 \\
\hline
\end{tabular}




\section{Table 6: The effects of political connections on corporate leverage}

This table presents second stage regression estimates from a Hackman two-stage regression of book leverage of the firm on political connections and all other control variables. Standard errors are reported in brackets. ${ }^{* * *}, * *$, And $*$ indicate statistical significance at the $1 \%, 5 \%$ and $10 \%$ levels.

\begin{tabular}{|c|c|c|c|}
\hline Variables & (I) & (II) & (III) \\
\hline Connected & $\begin{array}{c}0.101 * * * \\
(0.023)\end{array}$ & & \\
\hline Connected 1 & & $\begin{array}{c}0.129 * * * \\
(0.018)\end{array}$ & \\
\hline Connected2 & & & $\begin{array}{c}0.145^{* * *} \\
(0.030)\end{array}$ \\
\hline Firm Size & $\begin{array}{c}0.014 * * * \\
(0.009)\end{array}$ & $\begin{array}{c}0.012^{* * *} \\
(0.011)\end{array}$ & $\begin{array}{c}0.015^{* * *} \\
(0.018)\end{array}$ \\
\hline Tangible Assets & $\begin{array}{c}0.059 * * * \\
(0.010)\end{array}$ & $\begin{array}{c}0.063 * * \\
(0.008)\end{array}$ & $\begin{array}{c}0.060^{* *} \\
(0.015)\end{array}$ \\
\hline Profitability & $\begin{array}{c}-0.096 * * * \\
(0.021)\end{array}$ & $\begin{array}{c}-0.098 * * \\
(0.014)\end{array}$ & $\begin{array}{c}-0.100^{* *} \\
(0.030)\end{array}$ \\
\hline Growth Opportunities & $\begin{array}{c}-0.157^{* *} \\
(0.048)\end{array}$ & $\begin{array}{c}-0.140 * * \\
(0.050)\end{array}$ & $\begin{array}{l}-0.164^{*} \\
(0.081)\end{array}$ \\
\hline Foreign Ownership & $\begin{array}{l}-0.012 \\
(0.030)\end{array}$ & $\begin{array}{l}-0.014 \\
(0.041)\end{array}$ & $\begin{array}{l}-0.009 \\
(0.015)\end{array}$ \\
\hline Business Group Affiliation & $\begin{array}{c}0.310 * * * \\
(0.049)\end{array}$ & $\begin{array}{c}0.331 * * * \\
(0.074)\end{array}$ & $\begin{array}{c}0.357 * * * \\
(0.030)\end{array}$ \\
\hline Large Shareholders & $\begin{array}{c}0.110 \\
(0.283)\end{array}$ & $\begin{array}{c}0.096 \\
(0.341)\end{array}$ & $\begin{array}{c}0.102 \\
(0.263)\end{array}$ \\
\hline Board Independence & $\begin{array}{c}0.002 * * * \\
(0.000)\end{array}$ & $\begin{array}{c}0.002 * * * \\
(0.000)\end{array}$ & $\begin{array}{c}0.001 * * * \\
(0.000)\end{array}$ \\
\hline CEO Duality & $\begin{array}{c}0.048 \\
(0.115)\end{array}$ & $\begin{array}{c}0.057 \\
(0.090)\end{array}$ & $\begin{array}{c}0.056 \\
(0.212)\end{array}$ \\
\hline Inverse Mills ratio $(\lambda)$ & $\begin{array}{c}0.030 \\
(0.055)\end{array}$ & $\begin{array}{c}0.033 \\
(0.071)\end{array}$ & $\begin{array}{l}0.023^{*} \\
(0.012)\end{array}$ \\
\hline Year dummies & Yes & Yes & Yes \\
\hline Ind_Food & $\begin{array}{l}-0.014 \\
(0.050)\end{array}$ & $\begin{array}{l}-0.011 \\
(0.036)\end{array}$ & $\begin{array}{l}-0.020 \\
(0.064)\end{array}$ \\
\hline Ind_Basic & $\begin{array}{l}0.049^{*} \\
(0.023)\end{array}$ & $\begin{array}{l}0.052^{*} \\
(0.026)\end{array}$ & $\begin{array}{l}0.050^{*} \\
(0.025)\end{array}$ \\
\hline Ind_Const & $\begin{array}{c}0.604 * * * \\
(0.091)\end{array}$ & $\begin{array}{c}0.588 * * * \\
(0.105)\end{array}$ & $\begin{array}{c}0.599 * * * \\
(0.120)\end{array}$ \\
\hline Ind_Textile & $\begin{array}{c}0.112 * * * \\
(0.014)\end{array}$ & $\begin{array}{c}0.108^{* * * *} \\
(0.023)\end{array}$ & $\begin{array}{c}0.119^{* * * *} \\
(0.020)\end{array}$ \\
\hline Ind_Consumer & $\begin{array}{l}-0.005 \\
(0.010)\end{array}$ & $\begin{array}{l}-0.008 \\
(0.016)\end{array}$ & $\begin{array}{l}-0.001 \\
(0.008)\end{array}$ \\
\hline Ind_Transp & $\begin{array}{c}1.102 \\
(1.496)\end{array}$ & $\begin{array}{l}1.085 \\
(2.723)\end{array}$ & $\begin{array}{l}1.110 \\
(3.602)\end{array}$ \\
\hline Ind_Services & $\begin{array}{l}-0.000 \\
(0.004)\end{array}$ & $\begin{array}{l}-0.001 \\
(0.005)\end{array}$ & $\begin{array}{l}-0.002 \\
(0.002)\end{array}$ \\
\hline N. & 2328 & 2328 & 2328 \\
\hline $\mathrm{R}$-square & 0.246 & 0.219 & 0.232 \\
\hline
\end{tabular}




\section{Table 7: The effects of political connections on excess cash holdings}

This table presents second stage regression estimates from a Hackman two-stage regression of cash holdings on political connections and all other control variables. Standard errors are reported in brackets. $* * *, * *$, And * indicate statistical significance at the $1 \%, 5 \%$ and $10 \%$ levels.

\begin{tabular}{|c|c|c|c|}
\hline Variables & (I) & (II) & (III) \\
\hline Connected & $\begin{array}{c}0.021 * * * \\
(0.012)\end{array}$ & & \\
\hline Connected1 & & $\begin{array}{c}0.027 * * * \\
(0.021)\end{array}$ & \\
\hline Connected2 & & & $\begin{array}{c}0.035^{* * *} \\
(0.016)\end{array}$ \\
\hline Firm Size & $\begin{array}{c}-0.034 * * \\
(0.010)\end{array}$ & $\begin{array}{c}-0.032 * * \\
(0.009)\end{array}$ & $\begin{array}{c}-0.029 * * \\
(0.010)\end{array}$ \\
\hline Net Working Capital & $\begin{array}{c}-0.051 \\
(0.176)\end{array}$ & $\begin{array}{c}-0.055 \\
(0.248)\end{array}$ & $\begin{array}{l}-0.058 \\
(0.194)\end{array}$ \\
\hline Growth Opportunities & $\begin{array}{c}0.009 \\
(0.020)\end{array}$ & $\begin{array}{c}0.010 \\
(0.013)\end{array}$ & $\begin{array}{c}0.010 \\
(0.014)\end{array}$ \\
\hline Dividend Payment & $\begin{array}{l}-0.112 * \\
(0.055)\end{array}$ & $\begin{array}{l}-0.097 * \\
(0.043)\end{array}$ & $\begin{array}{l}-0.118^{*} \\
(0.057)\end{array}$ \\
\hline Liabilities & $\begin{array}{c}-0.109 * * * \\
(0.013)\end{array}$ & $\begin{array}{c}-0.107 * * * \\
(0.022)\end{array}$ & $\begin{array}{c}-0.113 * * * \\
(0.010)\end{array}$ \\
\hline Business Group Affiliation & $\begin{array}{c}0.075 \\
(0.210)\end{array}$ & $\begin{array}{c}0.060 \\
(0.111)\end{array}$ & $\begin{array}{c}0.081 \\
(0.249)\end{array}$ \\
\hline Large Shareholders & $\begin{array}{c}0.009 \\
(0.026)\end{array}$ & $\begin{array}{c}0.010 \\
(0.014)\end{array}$ & $\begin{array}{c}0.012 \\
(0.030)\end{array}$ \\
\hline Board Independence & $\begin{array}{c}-0.004 * * * \\
(0.001)\end{array}$ & $\begin{array}{c}-0.005^{* * *} \\
(0.001)\end{array}$ & $\begin{array}{c}-0.002 * * * \\
(0.000)\end{array}$ \\
\hline CEO Duality & $\begin{array}{l}-0.012 \\
(0.041)\end{array}$ & $\begin{array}{l}-0.013 \\
(0.050)\end{array}$ & $\begin{array}{c}-0.010 \\
(0.018)\end{array}$ \\
\hline Inverse Mills ratio $(\lambda)$ & $\begin{array}{c}0.004 \\
(0.009)\end{array}$ & $\begin{array}{c}0.010 \\
(0.016)\end{array}$ & $\begin{array}{c}0.006 \\
(0.019)\end{array}$ \\
\hline Year dummies & Yes & Yes & Yes \\
\hline Ind_Food & $\begin{array}{l}-0.011 \\
(0.042)\end{array}$ & $\begin{array}{l}-0.009 \\
(0.056)\end{array}$ & $\begin{array}{l}-0.013 \\
(0.035)\end{array}$ \\
\hline Ind_Basic & $\begin{array}{c}0.108 \\
(0.351)\end{array}$ & $\begin{array}{c}0.116 \\
(0.405)\end{array}$ & $\begin{array}{c}0.105 \\
(0.534)\end{array}$ \\
\hline Ind_Const & $\begin{array}{c}0.152 * * * \\
(0.018)\end{array}$ & $\begin{array}{c}0.147 * * * \\
(0.030)\end{array}$ & $\begin{array}{c}0.151 * * * \\
(0.022)\end{array}$ \\
\hline Ind_Textile & $\begin{array}{c}-0.016^{* * *} \\
(0.003)\end{array}$ & $\begin{array}{c}-0.020 * * * \\
(0.004)\end{array}$ & $\begin{array}{c}-0.018^{* * * *} \\
(0.002)\end{array}$ \\
\hline Ind_Consumer & $\begin{array}{c}1.134 * * * \\
(0.201)\end{array}$ & $\begin{array}{c}1.098 * * * \\
(0.136)\end{array}$ & $\begin{array}{c}1.110 * * * \\
(0.095)\end{array}$ \\
\hline Ind_Transp & $\begin{array}{c}0.002 \\
(0.004)\end{array}$ & $\begin{array}{c}0.001 \\
(0.001)\end{array}$ & $\begin{array}{c}0.000 \\
(0.001)\end{array}$ \\
\hline Ind_Services & $\begin{array}{l}0.008^{*} \\
(0.003)\end{array}$ & $\begin{array}{l}0.007^{*} \\
(0.004)\end{array}$ & $\begin{array}{l}0.005^{*} \\
(0.002)\end{array}$ \\
\hline N. & 2328 & 2328 & 2328 \\
\hline R-square & 0.212 & 0.195 & 0.231 \\
\hline
\end{tabular}


Table 8: The effects of political connections on accruals management

This table presents second stage regression estimates from a Hackman two-stage regression of absolute and actual accruals on political connections and all other control variables. Standard errors are reported in brackets. ***, **, And * indicate statistical significance at the $1 \%, 5 \%$ and $10 \%$ levels.

\begin{tabular}{|c|c|c|c|c|c|c|}
\hline \multirow[b]{2}{*}{ Variables } & \multicolumn{3}{|c|}{ Panel A: Absolute accruals } & \multicolumn{3}{|c|}{ Panel B: Original accruals } \\
\hline & (I) & (II) & (III) & (I) & (II) & (III) \\
\hline Connected & $\begin{array}{c}0.051 * * * \\
(0.008)\end{array}$ & & & $\begin{array}{l}0.034^{*} \\
(0.016)\end{array}$ & & \\
\hline Connected 1 & & $\begin{array}{c}0.064 * * * \\
(0.013)\end{array}$ & & & $\begin{array}{l}0.031 * \\
(0.014)\end{array}$ & \\
\hline Connected2 & & & $\begin{array}{c}0.081 * * * \\
(0.020)\end{array}$ & & & $\begin{array}{l}0.055^{*} \\
(0.027)\end{array}$ \\
\hline Firm Size & $\begin{array}{c}-0.091 * * * \\
(0.020)\end{array}$ & $\begin{array}{c}-0.086^{* * *} \\
(0.015)\end{array}$ & $\begin{array}{c}-0.0097 * * * \\
(0.022)\end{array}$ & $\begin{array}{c}-0.026^{* * *} \\
(0.001)\end{array}$ & $\begin{array}{c}-0.027^{* * *} \\
(0.000)\end{array}$ & $\begin{array}{c}-0.025 * * * \\
(0.003)\end{array}$ \\
\hline Leverage & $\begin{array}{c}-0.178 * * * \\
(0.032)\end{array}$ & $\begin{array}{c}-0.174 * * * \\
(0.041)\end{array}$ & $\begin{array}{c}-0.181 * * * \\
(0.016)\end{array}$ & $\begin{array}{c}-0.159 * \\
(0.082)\end{array}$ & $\begin{array}{l}-0.151 * \\
(0.078)\end{array}$ & $\begin{array}{l}-0.155^{*} \\
(0.067)\end{array}$ \\
\hline Growth Opportunities & $\begin{array}{c}0.376^{* * *} \\
(0.082)\end{array}$ & $\begin{array}{c}0.370 * * * \\
(0.061)\end{array}$ & $\begin{array}{c}0.380 * * * \\
(0.051)\end{array}$ & $\begin{array}{c}0.314 * * * \\
(0.021)\end{array}$ & $\begin{array}{c}0.301 * * * \\
(0.050)\end{array}$ & $\begin{array}{c}0.299 * * * \\
(0.062)\end{array}$ \\
\hline Large Shareholders & $\begin{array}{c}0.009 \\
(0.016)\end{array}$ & $\begin{array}{c}0.007 \\
(0.014)\end{array}$ & $\begin{array}{c}0.006 \\
(0.017)\end{array}$ & $\begin{array}{c}0.108 \\
(0.422)\end{array}$ & $\begin{array}{l}0.0102 \\
(0.321)\end{array}$ & $\begin{array}{c}0.100 \\
(0.303)\end{array}$ \\
\hline Board Independence & $\begin{array}{l}-0.001 * \\
(0.000)\end{array}$ & $\begin{array}{l}-0.000 * \\
(0.000)\end{array}$ & $\begin{array}{l}-0.001 * \\
(0.000)\end{array}$ & $\begin{array}{c}0.178 \\
(0.415)\end{array}$ & $\begin{array}{c}0.174 \\
(0.369)\end{array}$ & $\begin{array}{c}0.176 \\
(0.510)\end{array}$ \\
\hline CEO Duality & $\begin{array}{c}0.084 \\
(0.320)\end{array}$ & $\begin{array}{c}0.080 \\
(0.291)\end{array}$ & $\begin{array}{l}-0.079 \\
(0.401)\end{array}$ & $\begin{array}{c}0.139 \\
(0.282)\end{array}$ & $\begin{array}{c}0.140 \\
(0.203)\end{array}$ & $\begin{array}{c}0.142 \\
(0.325)\end{array}$ \\
\hline Inverse Mills ratio $(\lambda)$ & $\begin{array}{c}0.086 \\
(0.275)\end{array}$ & $\begin{array}{c}0.091 \\
(0.327)\end{array}$ & $\begin{array}{c}0.103 \\
(0.384)\end{array}$ & $\begin{array}{c}0.014 \\
(0.051)\end{array}$ & $\begin{array}{l}0.020^{*} \\
(0.010)\end{array}$ & $\begin{array}{c}0.011 \\
(0.007)\end{array}$ \\
\hline Year dummies & Yes & Yes & Yes & Yes & Yes & Yes \\
\hline Ind_Food & $\begin{array}{c}0.092 \\
(0.305)\end{array}$ & $\begin{array}{c}0.098 \\
(0.279)\end{array}$ & $\begin{array}{c}0.087 \\
(0.214)\end{array}$ & $\begin{array}{c}0.061 \\
(0.205)\end{array}$ & $\begin{array}{c}0.058 \\
(0.182)\end{array}$ & $\begin{array}{c}0.064 \\
(0.129)\end{array}$ \\
\hline Ind_Basic & $\begin{array}{c}0.001 \\
(0.000)\end{array}$ & $\begin{array}{c}0.000 \\
(0.000)\end{array}$ & $\begin{array}{c}0.001 \\
(0.000)\end{array}$ & $\begin{array}{c}0.002 \\
(0.000)\end{array}$ & $\begin{array}{c}0.000 \\
(0.000)\end{array}$ & $\begin{array}{c}0.001 \\
(0.000)\end{array}$ \\
\hline Ind_Const & $\begin{array}{l}-0.274^{*} \\
(0.138)\end{array}$ & $\begin{array}{l}-0.270 * \\
(0.141)\end{array}$ & $\begin{array}{l}-0.258 * \\
(0.135)\end{array}$ & $\begin{array}{l}-0.281 * \\
(0.140)\end{array}$ & $\begin{array}{l}-0.273 * \\
(0.132)\end{array}$ & $\begin{array}{l}-0.251 * \\
(0.128)\end{array}$ \\
\hline Ind_Textile & $\begin{array}{l}-0.115 \\
(0.389)\end{array}$ & $\begin{array}{l}-0.122 \\
(0.435)\end{array}$ & $\begin{array}{c}-0.120 \\
(0.492)\end{array}$ & $\begin{array}{l}-0.139 \\
(0.251)\end{array}$ & $\begin{array}{l}-0.141 \\
(0.275)\end{array}$ & $\begin{array}{l}-0.140 \\
(0.288)\end{array}$ \\
\hline Ind_Consumer & $\begin{array}{c}0.519 \\
(1.021)\end{array}$ & $\begin{array}{c}0.490 \\
(0.910)\end{array}$ & $\begin{array}{c}0.531 \\
(0.818)\end{array}$ & $\begin{array}{c}0.630 \\
(1.105)\end{array}$ & $\begin{array}{c}0.611 \\
(1.002)\end{array}$ & $\begin{array}{c}0.640 \\
(1.230)\end{array}$ \\
\hline Ind_Transp & $\begin{array}{c}0.000 \\
(0.000)\end{array}$ & $\begin{array}{c}0.000 \\
(0.000)\end{array}$ & $\begin{array}{l}0.001^{*} \\
(0.000)\end{array}$ & $\begin{array}{c}0.001 \\
(0.001)\end{array}$ & $\begin{array}{c}0.000 \\
(0.000)\end{array}$ & $\begin{array}{l}0.000^{*} \\
(0.000)\end{array}$ \\
\hline Ind_Services & $\begin{array}{c}0.026 * * * \\
(0.004)\end{array}$ & $\begin{array}{c}0.024 * * * \\
(0.005)\end{array}$ & $\begin{array}{c}0.028 * * * \\
(0.002)\end{array}$ & $\begin{array}{c}0.012 * * * \\
(0.001)\end{array}$ & $\begin{array}{c}0.010^{* * *} \\
(0.002)\end{array}$ & $\begin{array}{c}0.013 * * * \\
(0.002)\end{array}$ \\
\hline N. & 2328 & 2328 & 2328 & 2328 & 2328 & 2328 \\
\hline R-square & 0.260 & 0.221 & 0.226 & 0.202 & 0.186 & 0.219 \\
\hline
\end{tabular}


Table 9: Robustness tests

This table presents the robustness tests results. The dependent variables in the models I to IV are Leverage, Excess Cash and the Abnormal Accruals of the firm. Standard errors are reported in brackets. $* * *, * *$, And $*$ indicate statistical significance at the $1 \%, 5 \%$ and $10 \%$ levels.

\begin{tabular}{|c|c|c|c|}
\hline \multicolumn{4}{|c|}{ Panel A: Alternative definitions of financial policies variables } \\
\hline Variables & (I) & (II) & (III) \\
\hline \multicolumn{4}{|c|}{ Model I: Leverage } \\
\hline Connected & $\begin{array}{c}0.081 * * \\
(0.023)\end{array}$ & & \\
\hline Connected 1 & & $\begin{array}{c}0.092^{* *} \\
(0.030)\end{array}$ & \\
\hline Connected 2 & & & $\begin{array}{c}0.104 * * \\
(0.034)\end{array}$ \\
\hline R-square & 0.309 & 0.253 & 0.270 \\
\hline N. & 2328 & 2328 & 2328 \\
\hline \multicolumn{4}{|c|}{ Model II: Excess Cash } \\
\hline Connected & $\begin{array}{c}0.064^{*} \\
(0.033)\end{array}$ & & \\
\hline Connected 1 & & $\begin{array}{c}0.070^{* *} \\
(0.025)\end{array}$ & \\
\hline Connected 2 & & & $\begin{array}{c}0.85^{* * *} \\
(0.010)\end{array}$ \\
\hline R-square & 0.186 & 0.217 & 0.243 \\
\hline N. & 2328 & 2328 & 2328 \\
\hline \multicolumn{4}{|c|}{ Model III: Accruals Management } \\
\hline Connected & $\begin{array}{r}0.044^{* *} \\
(0.005)\end{array}$ & & \\
\hline Connected 1 & & $\begin{array}{c}0.067 * * * \\
(0.012)\end{array}$ & \\
\hline Connected 2 & & & $\begin{array}{c}0.080^{* * * *} \\
(0.013)\end{array}$ \\
\hline R-square & 0.236 & 0.205 & 0.187 \\
\hline N. & 2328 & 2328 & 2328 \\
\hline
\end{tabular}

Panel B: Inclusion of other measures of corporate governance

\begin{tabular}{lccc}
\hline \hline & Model I: Leverage & \\
\hline Connected & $0.080^{* * *}$ & & \\
& $(0.021)$ & $0.095^{* * *}$ & \\
Connected1 & & $(0.029)$ & $0.101^{* * *}$ \\
& & & $(0.010)$ \\
Connected2 & & & \\
& & & \\
Foreign Listing $\times$ Connected & $-0.014^{*}$ & $-0.035^{*}$ & \\
Foreign Listing $\times$ Connected1 & $(0.006)$ & $(0.016)$ & $-0.028^{*}$ \\
& & & $(0.013)$ \\
Foreign Listing $\times$ Connected2 & & & $-0.008^{* * *}$ \\
& & $-0.002^{* * *}$ & $(0.002)$ \\
Foreign Listing & $-0.005^{* * *}$ & $(0.000)$ & 0.187 \\
R-square & $(0.001)$ & 0.204 & 2328 \\
N. & 0.215 & 2328 & \\
\hline
\end{tabular}

Model II: Excess Cash 


\begin{tabular}{|c|c|c|c|}
\hline Connected & $\begin{array}{c}0.079 * * * \\
(0.006)\end{array}$ & & \\
\hline Connected 1 & & $\begin{array}{c}0.088^{* * * *} \\
(0.024)\end{array}$ & \\
\hline Connected2 & & & $\begin{array}{c}0.114 * * * \\
(0.030)\end{array}$ \\
\hline Foreign Listing $\times$ Connected & $\begin{array}{c}0.125 \\
(0.402)\end{array}$ & & \\
\hline Foreign Listing $\times$ Connected 1 & & $\begin{array}{c}0.118 \\
(0.258)\end{array}$ & \\
\hline Foreign Listing $\times$ Connected 2 & & & $\begin{array}{c}0.132 \\
(0.374)\end{array}$ \\
\hline Foreign Listing & $\begin{array}{c}0.052 \\
(0.107)\end{array}$ & $\begin{array}{c}0.045 \\
(0.093)\end{array}$ & $\begin{array}{c}0.047 \\
(0.082)\end{array}$ \\
\hline R-square & 0.274 & 0.221 & 0.236 \\
\hline N. & 2328 & 2328 & 2328 \\
\hline \multicolumn{4}{|c|}{ Model III: Accruals Management } \\
\hline Connected & $\begin{array}{c}0.054^{* * * *} \\
(0.009)\end{array}$ & & \\
\hline Connected 1 & & $\begin{array}{l}0.073^{* *} \\
(0.015)\end{array}$ & \\
\hline Connected2 & & & $\begin{array}{c}0.090^{* * * *} \\
(0.020)\end{array}$ \\
\hline Foreign Listing $\times$ Connected & $\begin{array}{c}0.005 \\
(0.010)\end{array}$ & & \\
\hline Foreign Listing $\times$ Connected 1 & & $\begin{array}{c}0.003 \\
(0.020)\end{array}$ & \\
\hline Foreign Listing $\times$ Connected 2 & & & $\begin{array}{c}0.000 \\
(0.001)\end{array}$ \\
\hline Foreign Listing & $\begin{array}{c}0.012 \\
(0.046)\end{array}$ & $\begin{array}{c}0.010 \\
(0.014)\end{array}$ & $\begin{array}{c}0.018 \\
(0.053)\end{array}$ \\
\hline R-square & 0.313 & 0.261 & 0.274 \\
\hline $\mathrm{N}$. & 2328 & 2328 & 2328 \\
\hline
\end{tabular}

Panel C: Alternative estimation techniques

Pooled regressions

\begin{tabular}{lccc}
\hline \multicolumn{4}{c}{ Model I: Leverage } \\
\\
Connected & $0.072^{* * *}$ & & \\
& $(0.011)$ & $0.085^{* * *}$ & \\
Connected1 & & $(0.009)$ & $0.106^{* * *}$ \\
& & & $(0.021)$ \\
Connected2 & & 0.299 & 403 \\
R-square & 0.281 & 403 & \\
N. & 403 & & \\
\hline & Model II: Excess Cash & \\
\hline Connected & $0.056^{* * *}$ & & \\
Connected1 & $(0.008)$ & $0.062^{* *}$ & \\
& & $(0.024)$ &
\end{tabular}




\begin{tabular}{lccc} 
& \multicolumn{2}{c}{$(0.009)$} \\
R-square & 0.168 & 0.189 & 0.204 \\
N. & 403 & 403 & 403 \\
\hline & Model III: Accruals Management & \\
\hline Connected & $0.065^{* * *}$ & \\
Connected1 & $(0.012)$ & & \\
Connected2 & & $0.081^{* * *}$ & \\
& & $(0.019)$ & $0.096^{* * *}$ \\
R-square & & & $(0.014)$ \\
N. & 0.214 & 0.230 & 0.208 \\
\hline
\end{tabular}

\section{Random effect regressions}

\begin{tabular}{|c|c|c|c|}
\hline \multicolumn{4}{|c|}{ Model I: Leverage } \\
\hline Connected & $\begin{array}{c}0.063 * * * \\
(0.003)\end{array}$ & & \\
\hline Connected 1 & & $\begin{array}{c}0.071 * * \\
(0.022)\end{array}$ & \\
\hline Connected 2 & & & $\begin{array}{c}0.097 * * \\
(0.031)\end{array}$ \\
\hline R-square & 0.310 & 0.239 & 0.195 \\
\hline N. & 2328 & 2328 & 2328 \\
\hline \multicolumn{4}{|c|}{ Model II: Excess Cash } \\
\hline Connected & $\begin{array}{c}0.076^{* * *} \\
(0.004)\end{array}$ & & \\
\hline Connected 1 & & $\begin{array}{c}0.090 * * * \\
(0.015)\end{array}$ & \\
\hline Connected2 & & & $\begin{array}{c}0.120 * * * \\
(0.031)\end{array}$ \\
\hline R-square & 0.205 & 0.191 & 0.212 \\
\hline $\mathrm{N}$ & 2328 & 2328 & 2328 \\
\hline \multicolumn{4}{|c|}{ Model III: Accruals Management } \\
\hline Connected & $\begin{array}{c}0.039 * * * \\
(0.001)\end{array}$ & & \\
\hline Connected 1 & & $\begin{array}{c}0.058 * * \\
(0.019)\end{array}$ & \\
\hline Connected 2 & & & $\begin{array}{c}0.080 * * \\
(0.026)\end{array}$ \\
\hline R-square & 0.232 & 0.196 & 0.225 \\
\hline N. & 2,328 & 2,328 & 2,328 \\
\hline
\end{tabular}

